NBER WORKING PAPER SERIES

\title{
THE SAHM RULE AND PREDICTING THE GREAT RECESSION ACROSS OECD COUNTRIES
}

\author{
David G. Blanchflower \\ Alex Bryson \\ Working Paper 29300 \\ http://www.nber.org/papers/w29300
NATIONAL BUREAU OF ECONOMIC RESEARCH
1050 Massachusetts Avenue
Cambridge, MA 02138
September 2021

We thank Phillipa Dunn, David Kotok, Claudia Sahm, and Chris Williamson for their help with this paper. The views expressed herein are those of the authors and do not necessarily reflect the views of the National Bureau of Economic Research.

NBER working papers are circulated for discussion and comment purposes. They have not been peer-reviewed or been subject to the review by the NBER Board of Directors that accompanies official NBER publications.

(C) 2021 by David G. Blanchflower and Alex Bryson. All rights reserved. Short sections of text, not to exceed two paragraphs, may be quoted without explicit permission provided that full credit, including $\left({ }^{\circ}\right.$ notice, is given to the source. 
The Sahm Rule and Predicting the Great Recession Across OECD Countries

David G. Blanchflower and Alex Bryson

NBER Working Paper No. 29300

September 2021

JEL No. E17,J60,J64

\begin{abstract}
$\underline{\text { ABSTRACT }}$
We examine the start date of the Great Recession across OECD countries based on two successive quarters of negative GDP growth recession. For most OECD countries this establishes the start of recession in Q22008 or Q32008. We find that the Sahm Rule identifies the start of recession in the US to the beginning of 2008 but in other OECD countries it identifies the start in almost every case, after that identified by GDP. But the GDP and labor market data are subject to major revisions, so the turn is not apparent in most countries for some time. We establish our own rule for predicting recession using the fear of unemployment series to predict recession. It involves looking for a ten-point rise in the series compared to its previous twelve month low. These surveys are timely and have the major advantage they are not subject to revision. Across the OECD we confirm this finding with other types of qualitative data and especially so in the UK. Qualitative surveys, we show, in the US in 2006 and 2007 predicted the subsequent recession and they did the same in Europe at the end of 2007 and in the early part of 2008.
\end{abstract}

David G. Blanchflower

Bruce V. Rauner Professor of Economics

6106 Rockefeller Hall

Dartmouth College

Hanover, NH 03755-3514

and Adam Smith School of Business, University of Glasgow

and also NBER

David.G.Blanchflower@Dartmouth.EDU

\author{
Alex Bryson \\ Professor of Quantitative Social Science \\ UCL Social Research Institute \\ University College London \\ 20 Bedford Way \\ London WC1H 0AL \\ United Kingdom \\ a.bryson@ucl.ac.uk
}


"(O)ne would need to be endowed with perfect foresight to have been able to predict how the financial crisis would unfold, spilling over from one institution to another, and from one market to another. ...The moral from this is one should not expect to be able to predict the timing and scale of these sorts of events with any precision". Charlie Bean, Deputy Governor for Monetary Policy at the Bank of England, speech to the Royal Statistical Society User Forum, London, 27 ${ }^{\text {th }}$ October 2010.

There was no need for perfect foresight to predict the Great Recession of 2008; following the data was enough. Turning points, admittedly, are hard to spot, both downturns and upturns although the former matter more. Being overly optimistic at a turn down is likely worse than being too pessimistic about an uptick, especially if institutions and investors limit their exposures in the face of a predicted downturn that does not come. Inevitably estimation involves extrapolation of existing trends, hence at down turns estimates tend to be too high and at upticks, they tend to be too low. Real time data are also problematic: quarterly GDP estimates are constantly revised by statistical authorities as new data arrive, so early releases tend to have a high proportion of estimate and little data. As time goes on more data arrive and the estimated proportion declines. As we shall see below there are also issues with revisions to labor market data.

The simplest way to identify the start of a recession outside the United States is to see when there are two successive negative quarterly growth estimates for GDP. The problem in spotting the timing of the Great Recession was that initial estimates of GDP change at the turning point were heavily revised. We only know definitively when the start of the Great Recession began a decade or so later. As data come in over time the estimates at the turning points tend to be revised a lot, but it takes a while. ${ }^{1}$ Consequently policymakers have little sound information in real time to make judgements about the past, the present and the future. The MPC in its August 2008 Inflation Report wrongly forecast no recession but also in its backcast assumed the past and the present would be revised upwards, which they were not. Chart 1 presents the MPC's forecast and backcast, from August 2008, five months after recession in the UK started and many months after it started in the USA. The forecast band widens to the right as the further out the forecast the greater the errors. It shows that the central forecast is no recession in the future, as the green swathe does not go below zero.

The green band to the left narrows due to revisions over time becoming more accurate and the black line is the latest data from the ONS. The fact that the green band is above the ONS line implies the MPC expects data from the past, and the present, to be revised up. It wasn't and as we show below there was a recession that lasted five quarters from Q22008-Q22009. The forecast was conditioned on market interest rates which at the time suggested they would remain above $5 \%$ for the duration of the forecast, which turned out to be too high, given that rates were cut to 0.5 by March 2009. Getting GDP revisions wrong really matters.

\footnotetext{
${ }^{1}$ For example, in the UK in May 1992 the first estimate of quarterly GDP growth for Q21992 was published as $-0.7 \%$ and is now $0 \%$. This estimate has subsequently been revised twelve times as follows Jun- $92=-0.5 \%$; Sept- $92=-0.4 \%$; Sept-93=-0.6\%; Jun-95 $=-0.7 \%$; Sept-98 $=-0.1 \%$; Sept-01 $=+0.1 \%$; Sept-03 $=+0.3 \%$; Jun-06 $=+0.2 \%$; Sept $-08=+0.1 \%$; Jun-12=+0.3\%; Jun-13=+0.6\%; Sept-14=0\%.

https://www.ons.gov.uk/economy/grossdomesticproductgdp/datasets/revisionstrianglesforukgdpabmi
} 
A major issue is what data is available to call the start of recession, and when? It turns out that qualitative data are available first, usually in the month it refers to, which as we will see is a major advantage because of its timeliness. ${ }^{2}$ Then labor market data is released, but the data takes time to collect and is also subject to revision. ${ }^{3}$ For example, the estimate of non-farm payrolls is revised for two subsequent months. In some countries labor market data are available much earlier than others. ${ }^{4}$ The UK is the slowest to produce national statistics although it does publish monthly estimates that it doesn't use as a national statistic because of their variability. ${ }^{5}$ Early estimates of quarterly GDP growth are usually available shortly after the quarter ends, but these data are open to revision.

Now a decade after the revisions we find that the qualitative data give an accurate early indicator of recession. In the US the labor market data turned down before the downturn in the revised GDP data. In contrast in almost all the other OECD countries declining GDP preceded labor market declines. This is what also happened during the COVID-19 pandemic when the US unemployment rate jumped from $3.5 \%$ in February to $19.8 \%$ in April, whereas other countries saw much lower and smaller rises in unemployment. ${ }^{6}$

This paper is a companion to Blanchflower and Bryson (2021) where we used panel data for 29 European countries over 439 months between 1985 and 2021 in an unbalanced country*month panel of just over 10000 observations, to predict changes in the unemployment rate 12 months in advance. This was based on individuals' fears of unemployment, their perceptions of the economic situation and their own household financial situation. We found fear of unemployment predicts subsequent changes in unemployment 12 months later in the presence of country fixed effects and lagged unemployment. Individuals' perceptions of the economic situation in the country and their

\footnotetext{
2 . For example, The European Commission released data for August 2021 for their Business and Consumer Surveys on 30th August 2021.

https://ec.europa.eu/info/business-economy-euro/indicators-statistics/economic-databases/business-and-consumersurveys/latest-business-and-consumer-surveys_en

${ }^{3}$ For example, at the end of each calendar year, the Bureau of Labor Statistics (BLS) re-estimates the seasonal factors for the Current Population Survey series by including another full year of data in the estimation process. For the major aggregate labor force series, however, the first-time revisions rarely alter the essential trends observed in the initial estimates. https://www.bls.gov/news.release/archives/empsit_05082020.htm

${ }^{4}$ For example, at the time of writing in early September 2021, the latest Employment Situation Report from the BLS reports the unemployment rate and employment for August 2021. In contrast in the UK data is available for AprilJune 2021, which is reported as May. In contrast in EU countries seasonally adjusted data are available for July 2021. https://www.bls.gov/news.release/pdf/empsit.pdf

https://ec.europa.eu/eurostat/documents/2995521/11563247/3-01092021-AP-EN.pdf/e045fa11-8a9e-6e60-696719088d96af8a?t=1630482630262

https://www.ons.gov.uk/employmentandlabormarket/peopleinwork/employmentandemployeetypes/datasets/summar yoflabormarketstatistics

${ }^{5}$ Spreadsheet X01 shows an unemployment rate of 4.9\% for April-21; 4.8\% for May-21and 4.4\% for Jun-21 and an overall unemployment rate for April-June of 4.7\%, which, confusingly, is reported as being for May-21.

https://www.ons.gov.uk/employmentandlabormarket/peopleinwork/employmentandemployeetypes/datasets/laborfor cesurveysinglemonthestimatesx01

6 The official US unemployment rate for April 2020 was $14.8 \%$ but $5 \%$ has to be added to it because of misclassification errors in the Current Population Surveys reported in the April 2020 Employment Situation Report (https://www.bls.gov/news.release/archives/empsit_05082020.htm) which is continuing. In the September 2021 report the unemployment rate was biased downwards by 0.3pp due to this misclassification error.
} 
own household finances also predict unemployment 12 months later. Business sentiment we also found to be predictive of unemployment 12 months later.

In this paper we focus in more detail on the Great Recession of 2007-2009. We examine the value of qualitative data and establish our own rule for predicting recessions. We compare it to the Sahm Rule that has been proposed as a way of identifying recessions in the United States by looking at movements in the unemployment rate. It has not previously been applied elsewhere. The labor market started loosening in the US before GDP started to fall. The complication in the USA is that there were not two successive quarters of negative growth until Q32008: Q12008 was negative, but Q42007 and Q22008 were positive.

We examined quarterly GDP growth rates in 2007 and 2008 in 39 OECD countries (Table 1). This is after more than a decade of revisions. Using the two successive quarters of negative growth to signal recession, seven countries did not conform to the rule - Australia, Bulgaria, Iceland, Korea, Malta, Norway, Poland and Slovakia. Norway, it should be noted, had three of five negative quarters from Q12008 while Iceland had negative growth in Q32007 (-2.2\%); Q12008 (-2.9\%); Q32008 (-5.6) and Q12009 (-10.1\%) but positive growth in Q42007 (+4.6\%); Q22008 (+3.6\%) and Q42008 (+6\%).

However, thirty-one countries did fully conform to the rule, and in all but one of these cases recession started in 2008. One saw growth starting in Q42007 (Estonia); and five in Q12008 (Finland, Ireland, Luxembourg, New Zealand and Sweden). Nine countries saw two quarters of negative growth starting in Q2008 (Denmark, France, Germany, Greece, Italy, Japan, Latvia Portugal and the UK) with ten in Q32008 (Austria, Belgium, Chile, Hungary, Lithuania, Netherlands, Russia, Slovenia, Spain and the USA). Finally, six countries saw their economic activity head downwards in Q42008 (Canada, Czechia, Israel, Mexico, Romania and Switzerland)

We have unemployment rates for all of these OECD countries and in the majority the Sahm Rule, which compares a three-month moving average of the present with the lowest value of the moving average over the preceding year, suggests recession started after the date indicated by two-quarter declining GDP. In sixteen countries the Sahm Rule suggests recession started in 2009 whereas in no case was that true using the two successive quarters rule. But that is an ex-post judgment. The Sahm Rule is likely to indicate a downturn, even before the GDP data does, given the long revision cycles at turning points as we show below in the case of the US and especially the UK.

We then examined qualitative data for 29 European countries, which seems to give a much better and more-timely indicator of turning points in 2008 than either the unemployment rate or GDP. We also focus on the UK where there were a number of qualitative series in the Spring of 2008 consistently suggested recession had started at that point. The official GDP estimates didn't show that until June 2009.

The remainder of this paper is structured as follows. The next section describes traditional means of identifying business cycle turning points in the United States and elsewhere. Section Two shows the value of the Sahm Rule in predicting the Great Recession across the United States and at statelevel. Section Three extends this analysis to previous US downturns. In Section Four we turn to the UK and show that the Sahm Rule does not perform so well. Instead, we show that qualitative 
metrics of economic activity available at the time were 'flashing red' and were good at predicting the onset of recession. Section Five presents similar evidence for the rest of the OECD. Section Six offers another rule for predicting recession based on percentage point shifts in the fear of unemployment. Section Seven concludes.

\section{Dating US Business Cycles}

We first need to look at, traditionally, how peaks of business cycles are identified. In the US there is an official committee. On December $1^{\text {st }}$, 2008, the NBER Business Cycle Dating Committee (BCDC) determined that a peak in economic activity occurred in the US economy exactly a year earlier in December 2007..$^{7}$ The peak marked the end of the expansion that began in November 2001 and, the NBER argued, the beginning of a recession. The expansion lasted 73 months; the previous expansion of the 1990s lasted 120 months. They noted that "the currently available estimates of quarterly aggregate real domestic production do not speak clearly about the date of a peak in activity". ${ }^{8}$ They noted that non-farm payrolls reached a peak in December 2007 and declined every month after that. The BCDC also noted that their preferred measure of real personal income less transfers peaked in December 2007 while industrial production peaked in January 2008. The unemployment rate for December 2007, was 5.0\% up from $4.7 \%$ in November.

No other country has the equivalent, to our knowledge of the BCDC. Instead, more informal ways are used to identify turning points. The most widely used rule is that two successive quarters of GDP constitute a recession. That presents a couple of problems as the NBER noted. The first is that GDP growth, as noted above, is revised for a long time and sometimes by a lot especially at turning points. But second, the rule often doesn't give a clear-cut answer of when a recession started. In some cases, there are not two successive quarters but may be alternating negative quarters (e.g. Norway) or one very large negative quarter (Slovakia).

The United States presented a particular problem in 2007/8. GDP growth in Q42007 was positive (0.6\%), Q12008 was negative (-0.4\%) while Q22008 was positive $(0.6 \%)$. It was then followed by three negative quarters. So according to the two successive quarters rule the US recession started in July 2008, at the start of the third quarter. In the US estimates are reported as annualized percentage growth rates so that is what we report here. Below we report the first to third and current final estimates of quarterly changes in GDP. As we can see below the first estimate for Q12008 was positive, but it eventually switched to negative. 2008Q3 and 2008Q4 became more negative over time and as the economy started to improve in Q1 and Q2 2009 the early estimates were revised up. Over time Q22008 has become more positive over time. The four quarters 2008Q3-2009Q2 were negative, suggesting the recession using GDP growth started in Q32008.

$\begin{array}{lrrrc}\text { Date } & \text { First } & \text { Second } & \text { Third } & \text { Most Recent } \\ \text { Q42007 } & 70.636 & 0.626 & 0.578 & 2.460 \\ \text { Q12008 } & 0.597 & 0.901 & 0.959 & -1.619\end{array}$

${ }^{7}$ https://www.nber.org/news/business-cycle-dating-committee-announcement-december-1-2008

${ }^{8}$ The NBER BCDC noted. "The product-side estimates fell slightly in 2007Q4, rose slightly in 2008Q1, rose again in 2008Q2, and fell slightly in 2008Q3. The income-side estimates reached their peak in 2007Q3, fell slightly in 2007Q4 and 2008Q1, rose slightly in 2008Q2 to a level below its peak in 2007Q3, and fell again in 2008Q3. Thus, the currently available estimates of quarterly aggregate real domestic production do not speak clearly about the date of a peak in activity.” After revisions the most recent estimates suggest that Q407 was positive; Q108 negative and Q208 positive. 


$\begin{array}{lrrrr}\text { Q22008 } & 1.889 & 3.278 & 2.825 & 2.310 \\ \text { Q32008 } & -0.252 & -0.514 & -0.511 & -2.091 \\ \text { Q42008 } & -3.804 & -6.248 & -6.342 & -8.452 \\ \text { Q12009 } & -6.144 & -5.719 & -5.493 & -4.581 \\ \text { Q22009 } & -1.017 & -1.014 & -0.738 & -0.675\end{array}$

As noted in Blanchflower and Bryson (2021) the problem in the UK was that the first estimate of GDP growth in Q22008 produced by the Office of National Statistics in July 2008 was of growth of $+0.2 \%$. It took until June 2009 for that estimate to turn negative: it is currently $-0.6 \%$. In October 2008 Q32008 was reported at -0.5\% (now -2.0\%) and in January 2009 Q42008 was reported at $-1.5 \%$ (now $-2.3 \%$ ). So, from January through June 2009, it was wrongly thought the recession started in Q3 2008 whereas, in GDP terms it started in Q2. ${ }^{9}$ At downturns initial releases tend to overestimate growth.

What if we used labor market data? Appendix Table 1 reports monthly unemployment rates by country in 2007-2009 and shows that in the US the first big jump in the unemployment rate was between November and December 2007, from 4.7\% to 5.0\%. Table 2 shows changes in employment in the US from both the household and establishment surveys. ${ }^{10}$ Employment in the household survey declined first in April 2007 (-734k), was positive in May, June, September, November 2007 and January 2008 and then went negative from February 2008 and was negative in 22 of the next 24 months. Using a rule of two successive negative months of employment growth data gives the start of the US recession as July 2007 using household data. We find similarly below using state data.

In contrast non-farm payrolls first went negative in February 2008 and stayed negative for 22 of the next 23 months. The decline in employment over the period 2007-2009 was slightly larger on the household survey -7.96 million and on the establishment surveys 7.46 million which is to be expected given its broader scope. If we use non-farm payrolls that suggests that February 2008 was the start of the recession in the United States.

\section{The Great Recession, the Sahm Rule and the United States}

\subsection{The Sahm Rule}

For the United States, Claudia Sahm (2019) has invented the Sahm Rule, which identifies turning points in the unemployment rate, to identify the start of recession. It identifies signals related to the start of a recession when the three-month moving average of the national unemployment rate (U3) rises by 0.50 percentage points or more relative to the three-month moving average low during the previous 12 months. These data are available at FRED and plotted in Chart 2. ${ }^{11}$ The rule suggests February 2008 as the starting point of the Great Recession in the United States.

\footnotetext{
9 There were analogous issues on the upside, with the initial data releases tend to be underestimates. In July 2009 Q209 was reported at $-0.8 \%$ (now $-0.2 \%$ ) in October 2009 Q3 was reported as $-0.4 \%$ (now $+0.4 \%$ ) and in January 2010 Q409 was estimated at $+0.1 \%$ (now $+0.4 \%$ ).

https://www.ons.gov.uk/economy/grossdomesticproductgdp/datasets/revisionstrianglesforukgdpabmi

10 The household survey has a more expansive scope than the establishment survey because it includes self-employed workers whose businesses are unincorporated, unpaid family workers, agricultural workers, and private household workers, who are excluded by the establishment survey. See https://www.bls.gov/news.release/pdf/empsit.pdf

11 https://fred.stlouisfed.org/release?rid=456
} 
Data are also available on a broader measure of labor market slack that includes a measure of underemployment, the so-called U6 measure. That reached 0.50 in December 2007, the same month the BCDC called the recession. ${ }^{12}$ It is plotted in Chart 3. Feng and Sun (2020) suggest that the unemployment rate is subject to misclassification error due to difficulties in classifying some groups of people, like marginally attached worker and involuntary part-time workers who are included in the U6 variable. They also find that their corrected recession indicator identifies recession start dates a few months earlier than the original Sahm recession dates. Their indicator is rather complicated to calculate.

We also examined the unemployment rate by state and the Sahm Rule suggested that the first state to turn to recession was Florida as it did in the 1930s (Knowlton, 2021). ${ }^{13}$ There were ten states that began the recession, as measured by the Sahm Rule, in 2007. Alaska and North Dakota were the last to enter recession in December 2008.

$\begin{array}{ll}\text { April 2007 } & \text { Florida } \\ \text { June 2007 } & \text { Illinois } \\ \text { August 2007 } & \text { Nevada } \\ \text { September 2007 } & \text { California and Hawaii } \\ \text { October 2007 } & \text { Missouri, Montana and Tennessee } \\ \text { November 2007 } & \text { Colorado } \\ \text { December 2007 } & \text { Alabama and Georgia } \\ \text { January 2008 } & \text { Arizona and New York } \\ \text { February 2008 } & \text { Connecticut; Virginia and the USA } \\ \text { March 2008 } & \text { Delaware and New Jersey } \\ \text { April 2008 } & \text { Idaho and Utah } \\ \text { May 2008 } & \text { Indiana; Iowa; Michigan; Minnesota } \\ \text { June 2008 } & \text { DC; Kentucky; New Mexico; North Carolina; Ohio and Washington } \\ \text { July 2008 } & \text { Louisiana; Maryland; Massachusetts; Mississippi; Oregon; Pennsylvania; } \\ \text { August 2008 } & \text { Rhode Island and Vermont } \\ \text { October 2008 } & \text { Maine and Texas } \\ & \text { Arkansas; Kansas, New Hampshire, Oklahoma, South Dakota, Wisconsin } \\ \text { November 2008 } & \text { and Wyoming } \\ \text { December 2008 } & \text { Nebraska and West Virginia }\end{array}$

All fifty states plus DC saw their estimated Sahm Rule values hit 0.5 between April 2007 and December 2008.

\subsection{Employment declines by state}

We then examined employment growth by month by state as reported by the BLS and most states. We identified when there were two successive months of negative employment growth. Here we focus on employment levels. The data source is the Current Population Survey which includes the most marginal workers includes self-employed workers whose businesses are unincorporated,

\footnotetext{
${ }^{12}$ Bell and Blanchflower (2021) show that the underemployment rate (U7) is a better measure of labor market slack than the unemployment rate. They define U7 as PT for Economic Reasons divided by Employment.

${ }^{13}$ Spreadsheet available on request.
} 
unpaid family workers, agricultural workers, and private household workers, who are excluded by the establishment survey.

In the majority of states this occurred in 2007. Looking back at the US numbers for 2007 from Table 2, there were five months with negative growth (April, -734; July -158; August, -223; October -298 and December -332) including two successive ones (July and August). This is reflected by state also and it complicates determining starting points. The twelve-monthly observations for these thirty-three states with more than one successive negative monthly observation in 2007 are reported in Appendix Table 2.

Below we report the starting month, which is the first of two negative months of employment growth for twenty-one states that had one continuous spell of unemployment ranging from twelve months (Texas) to fifty-two months duration (Michigan). The details of the start and end dates of the spell and duration in continuous months is reported below. ${ }^{14}$

The earliest start, and the longest spell, was for Michigan in September 2005 lasting 52 months through December 2009. Vermont started in November 2006 with five others in 2007 and with the rest in 2008. Spells mostly lasted through the end of 2009 but in two cases they didn't end until 2010 (Colorado and Nevada) while two other starts didn’t complete their spell until 2011 (Arizona and Utah).

\begin{tabular}{lllcllll} 
& Start & End & Duration & & \multicolumn{2}{c}{ Start } & End Duration \\
Michigan & Sep-05 & Dec-09 & 52 & Utah & Feb-08 & Nov-11 & 34 \\
Vermont & Nov-06 & Dec-09 & 32 & Colorado & Mar-08 & Feb-10 & 24 \\
West Virginia & Jan-07 & Dec-09 & 20 & Arizona & May-08 & Jun-11 & 38 \\
Rhode Island & Feb-07 & Nov-09 & 34 & Nebraska & May-08 & Jan-10 & 21 \\
Florida & Mar-07 & Nov-09 & 33 & Georgia & Jul-08 & Aug-10 & 26 \\
South Carolina & Mar-07 & Nov-09 & 33 & N. Hampshire & Jul-08 & Nov-09 & 17 \\
Tennessee & Mar-07 & Aug-09 & 30 & Washington & Aug-08 & Dec-09 & 17 \\
Idaho & Jul-07 & Nov-09 & 28 & Virginia & Aug-08 & Dec-09 & 17 \\
California & Jan-08 & Dec-09 & 24 & Texas & Oct-08 & Sep-09 & 12 \\
Connecticut & Feb-08 & Dec-09 & 23 & Wyoming & Oct-08 & Dec-09 & 15 \\
Nevada & Feb-08 & Oct-10 & 33 & & & &
\end{tabular}

The remaining thirty states and DC had two broken spells, meaning two consecutive falls in employment level month on month followed by a subsequent spell of two consecutive falls but interrupted by months of growth. With the exception of Indiana, which started in December 2006, first spells all started between January and May 2007.

In Alabama, Kentucky and Missouri the second spell started in December 2007 but in all the other states it started in 2008. The finish date was also in 2008 except for Kansas and Missouri (January 2010), Oklahoma (October 2010) and Alabama (July 2011). Texas and Wyoming started last, in October 2008. The data are reported below.

14 Georgia had zero growth in May 2010 and Vermont had six positives interspersed in the 32 months. 


\begin{tabular}{|c|c|c|c|c|c|c|}
\hline & Start & End & Duration & Start & End & Duration \\
\hline Indiana & Dec-06 & Jul-07 & 8 & Apr-08 & Dec-09 & 21 \\
\hline Alabama & Jan-07 & Aug-07 & 2 & Nov-07 & Jul-11 & 45 \\
\hline Hawaii & Jan-07 & Sep-07 & 6 & Apr-08 & Oct-09 & 19 \\
\hline Illinois & Jan-07 & Mar-07 & 10 & Feb-08 & Dec-09 & 23 \\
\hline Maine & Jan-07 & Aug-07 & 7 & Apr-08 & Nov-09 & 20 \\
\hline Maryland & Jan-07 & Мау-07 & 10 & Apr-08 & Dec-09 & 21 \\
\hline Iowa & Jan-07 & Мay-07 & 15 & Sep-09 & Dec-09 & 16 \\
\hline Minnesota & Jan-07 & Oct-07 & 3 & Feb-08 & Oct-09 & 21 \\
\hline Mississippi & Jan-07 & Apr-07 & 9 & Feb-08 & Dec-09 & 23 \\
\hline New Jersey & Jan-07 & Jun-07 & 8 & Mar-08 & Nov-09 & 21 \\
\hline New York & Jan-07 & Jun-07 & 13 & Aug-08 & Dec-09 & 17 \\
\hline Alaska & Feb-07 & May-07 & 14 & Aug-08 & Oct-09 & 16 \\
\hline Arkansas & Feb-07 & Jul-07 & 10 & Jun-08 & Dec-09 & 12 \\
\hline Delaware & Feb-07 & Мay-07 & 9 & Mar-08 & Dec-09 & 22 \\
\hline Kansas & Feb-07 & Мay-07 & 12 & Jun-08 & Jan-10 & 16 \\
\hline Kentucky & Feb-07 & Sep-09 & 2 & Dec-07 & Nov-09 & 24 \\
\hline Missouri & Feb-07 & Aug-08 & 3 & Dec-07 & Jan-10 & 26 \\
\hline Oklahoma & Feb-07 & Jun-07 & 15 & Oct-10 & Nov-09 & 15 \\
\hline Wisconsin & Feb-07 & Jun-07 & 9 & Apr-08 & Dec-09 & 21 \\
\hline Louisiana & Mar-07 & Jun-07 & 14 & Sep-08 & Nov-09 & 15 \\
\hline North Carolina & Mar-07 & Мay-07 & 9 & Mar-08 & Nov-09 & 20 \\
\hline North Dakota & Mar-07 & Jun-07 & 13 & Aug-08 & Apr-09 & 9 \\
\hline Ohio & Mar-07 & Sep-07 & 4 & Feb-08 & Dec-09 & 23 \\
\hline Pennsylvania & Mar-07 & Apr-07 & 15 & Aug-08 & Dec-09 & 17 \\
\hline South Dakota & Mar-07 & Мау-07 & 10 & Apr-08 & Dec-09 & 21 \\
\hline $\mathrm{DC}$ & Apr-07 & Jun-07 & 13 & Aug-08 & Jun-09 & 11 \\
\hline New Mexico & Apr-07 & Мay-07 & 15 & Sep-08 & Dec-09 & 16 \\
\hline Massachusetts & May-07 & Aug-07 & 6 & Mar-08 & Nov-09 & 19 \\
\hline Montana & May-07 & Jul-07 & 7 & Mar-08 & Dec-09 & 22 \\
\hline Oregon & May-07 & Jul-07 & 12 & Aug-08 & Oct-09 & 15 \\
\hline USA & Jul-07 & Aug-07 & 2 & Feb-08 & Oct-09 & 21 \\
\hline
\end{tabular}

As an example of the prevalence of negative growth months, in May 2007, thirty-three states experienced negative growth in that month. This includes seven states with one ongoing spell and twenty-six in their first spell of two had negative growth in May. The exceptions are Arizona*, California*, Colorado*, Connecticut*, Georgia*, Idaho*, Illinois, Mississippi, Nebraska*, Nevada, NH*, Pennsylvania, Texas*, Utah, Virginia*, Washington*, WV and Wyoming*, where * notifies a long single spell to start in 2008.

As was clear from Table 2 the US had two successive negative months in July and August 2007 and then again in February 2008, with five months alternating positive to negative months and back. From February 2008 the US saw a spell of 22 negative months from Feb-08 through October 2009. From Nov-09 through Dec-10 there were another 7/14 months with negative growth. 
By July 2007, all but fourteen states in 2007 had also experienced at least two successive months of negative employment growth. That is also the date we get if we used two consecutive months of employment falls for the US as a whole. ${ }^{15}$

\subsection{Policymakers missed the Great Recession}

Despite many measures available with only a lag of a few weeks, suggesting the US labor market had been in recession for many months even by the summer of 2008 policymakers still seemed unaware. The transcript of the minutes of the FOMC meeting of August $5^{\text {th }}$, 2008, suggested that their next move of monetary policy was likely to be a tightening. ${ }^{16}$

"Most members did not see the current stance of policy as particularly accommodative, given that many households and businesses were facing elevated borrowing costs and reduced credit availability due to the effects of financial market strains as well as macroeconomic risks. Although members generally anticipated that the next policy move would likely be a tightening, the timing and extent of any change in policy stance would depend on evolving economic and financial developments and the implications for the outlook for economic growth and inflation.

Lehman Brothers went bankrupt in September 2008. At the October 2008 meeting the FOMC was forecasting in its Economic Projections that the central tendency of the unemployment rate would be $7.1 \%$ to $7.6 \%$ in 2009 and $6.5 \%$ to $7.3 \%$ in $2010 .{ }^{17}$ This was up from their economic projections in June 2008 of 5.3\% to 5.8\% in 2009 and 5.0\% to 5.6\% in 2010. Monthly unemployment in the US averaged $9.3 \%$ in 2009 and $9.6 \%$ in 2010, peaking at $10.0 \%$ in October 2009. This was a big miss.

\section{Previous US Downturns}

The following six peaks have been identified by the CBDC. ${ }^{18}$ 1) January 1980 (5 months) 2) July 1981 (6 months) 3) July 1990 (9 months) 4) March 2001 (8 months) 5) December 2007 (12 months) 6) February 2020 (4 months). The numbers in parentheses are how many months since the onset of recession it took the CBDC to call the recession.

However, if we were to simply use the two quarters of negative GDP growth rates that would show 11 recessions starting since Q21947. Appendix Table 3 reports GDP quarterly growth rates for the USA. In the 297 quarters from Q11948-Q22021 there have been forty-two quarters of negative growth and eleven recessions measured by two successive negative quarters of GDP growth. 1) Q21947 2) Q11949 3) Q31953 4) Q41957 5) Q41969 6) Q31974 7) Q21980 8) Q41981 9) Q41990 10) Q32008 11) Q12020.

\footnotetext{
${ }^{15}$ We should note that over the period January 1996 through July 2008 for the US there were only two prior occasions when there were two successive months of negative growth - April (-484) and May (-207) and November (-454) and December (-154) 2001, with the numbers in parentheses the employment decline in thousands. Since January 2011 there have only been two such spells -July (-99) and August (-1) 2012; March (-95) and April 2019 (-68) and March and the COVID declines in April 2020 (-3196 and -22,166).

${ }^{16}$ There was even a vote at this meeting to raise rates by Richard Fisher, Dallas Fed President "to help restrain inflation and inflation expectations, which were at risk of drifting higher".

${ }^{17}$ https://www.federalreserve.gov/monetarypolicy/fomcminutes20081029ep.htm and

https://www.federalreserve.gov/monetarypolicy/fomcminutes20080625ep.htm

${ }^{18}$ https://www.nber.org/research/business-cycle-dating/business-cycle-dating-committee-announcements
} 
Historically there are thirteen occasions between 1949 and August 2021 that the Sahm rule reaches 0.5 and hence, according to Sahm (2019) identifies the start of recession 1) November 1953 2) October 1957 3) November 1959 4) October 1960; 5) March 1970; 6) July 1974 7) February 1980 8) November 1981 9) October 1990 10) June 2001 11) November 2002 12) February 2008 13) April 2020.

It turns out that the Sahm Rule approximates very closely the starting dates for recession that would be identified if we simply looked at the starting data for two successive months of negative growth in either non-farm payrolls (NFP) or CPS employment. Table 3 illustrates. It reports monthly changes in NFP and CPS employment for the month identified as the start of the recession by the Sahm Rule (year t) plus five years earlier ( $t-1$ through $t-5)$ and three years later $(t+1$ through $t+3)$. The data identified as the start point (shown in green in the table) by the change in NFP is very close to the Sahm Rule date and is as follows

yeart-5 October 1957 and October 1960

yeart-4 November 2002

yeart-3 November 1953, November 1981 and June 2001

yeart-2 October 1990

yeart-1 April 2020

yeart February 2008

year $^{++1} \quad$ March 1970 and July 1974

year $_{\mathrm{t}+2}$ February 1980

November 1959 using NFP does not have two quarters of negative growth but does have negative growth in $\mathrm{t}-1$ and $\mathrm{t}-3$.

CPS employment, start dates are as follows

yeart-4 November 1953 and October 1990

yeart-2 June 2001

yeart-1 November 2002 and April 2020

year $_{t} \quad$ October 1957, November 1981and February 2008

year $t+1$ February 1980

yeart+2 October 1960 and March 1970

Two successive monthly negatives for CPS employment were not seen for November 1959 or July 1974.

Overall, in eight of the occasions the start based on NFP gives an earlier read than the Sahm Rule. On three occasions it was later and in the Great Recession they were the same. For the CPS five gave earlier starts, three were the same and one was a month later and two were two months later. If we just take the six NBER identified recessions since 1980 this is what we see.

$\begin{array}{lllll}\text { NBER } & \text { GDP } & \text { Sahm } & \text { NFP }\end{array}$

1) January $1980 \quad$ Q21980 $\quad$ February $1980 \quad$ February $1980 \quad$ March 1980

2) July $1981 \quad$ Q41981 November $1981 \quad$ September $1981 \quad$ November 1981 
3) July 1990

4) March 2001

Q41990

5) December $2007 \quad$ Q32008

6) February 2020. Q12020
October 1990

June 2001

February 2008

April 2020
August 1990

April 2001

February 2008

March 2008
July 1990

May 2001

January 2008

March 2020

If anything, the two-month employment decline rules using the NFP, and CPS give a slightly earlier read of NBER recession start dates than does the Sahm Rule. All three, though, are broadly consistent and give an earlier read than the BCDC.

The qualitative data in the US in the Great Recession gave an even earlier indication of what was coming in the United States. This is consistent with claims made in Blanchflower (2008) in April 2008, which examined how slowing started in the US housing market, first in prices which started falling at the end of 2006 and then spread to quantities such as permits to build, and housing starts, which slowed sharply in 2007. Consumer confidence data started falling around August 2007. Retail sales growth slowed from the spring of 2007 while real consumption and real disposable income slowed from around August 2007. As background Chart 4 plots the Michigan Consumer Confidence Index and the US unemployment rate which track each other pretty closely. As Blanchflower (2008) noted this started to decline from a peak of 96.9 in January 2007 to 75.5 in December 2007. By April 2008 it was clear the US was in recession. This led to the following conclusion. ${ }^{19}$

"By approximately December 2007 the housing market problems have now spilled over into real activity. The US seems to have moved into recession around the start of 2008."

The same process then followed in the UK a few months later, based on the equivalent data. Recession in the UK started in the housing market at the end of 2007 and, as in the US, spread far and wide. This led to the conclusion.

More bad news is on the way. I think it is very plausible that falling house prices will lead to a sharp drop in consumer spending growth. Developments in the UK are starting to look eerily similar to those in the US six months or so ago. There has been no decoupling of the two economies: contagion is in the air. The US sneezed and the UK is rapidly catching its cold," (Blanchflower, 2008).

As we show below that is exactly what happened across the OECD.

\section{The United Kingdom in the Great Recession 4.1.The Sahm Rule}

The Sahm Rule does not do such a good job in the UK. As noted in Table 1 above using the two negative quarters of GDP growth rule the recession started in the UK in April 2008. Table 4 presents the latest revised data for the UK by month for employment and its monthly change in the first two columns and the unemployment rate and the Sahm Rule estimates in columns 3 and 4 respectively. Employment growth goes negative in May 2008 and continues to be negative for eleven of the next thirteen months. The unemployment rate jumped from 5.2\% to 5.4\% in May 2008 - reported as April-June 2008 by the ONS.

\footnotetext{
19 The US qualitative data and a longer discussion to support this claim are reported in Blanchflower (2008).
} 
The Sahm Rule for the UK went to 0.5 in August 2008 (Chart 5). It does seem that the unemployment rate is more of a lagging indicator in the UK than it is in the United States. But we should note that is ten months before GDP growth in Q22008 was revised negative and Q32008 was not reported as negative until October 2008. Negative employment growth in two successive quarters does suggest the recession started three months earlier in May 2008.

\subsection{The fear of unemployment}

Blanchflower and Bryson (2021) have already noted that there is considerably more qualitative data for Europe in general than for the USA, including the EU Business and Consumer Surveys and the Purchasing Manager Indexes (PMI), plus for the UK there were the Bank of England Agent's monthly scores. The question is whether these help with turning points in 2008. Columns 6-8 of Table 4 for the UK report the fear of unemployment series from the EU Commission; the Bank of England Agents' Recruitment Difficulties score, and the Employment PMI from Markit. ${ }^{20}$ These are timely indicators available often in the relevant month itself and are not revised.

In particular we make use of qualitative survey data from the Joint EU Harmonized Programme of Business and Consumer Surveys conducted by the European Commission (EC). Our major focus here is on the fear of unemployment (Blanchflower, 1991; Blanchflower and Shadforth, 2009) expressed not just by workers but based on a sample of working and non-working adults.

The question asked is:

Q1. How do you expect the number of people unemployed in this country to change over the next 12 months? The number will...

++ increase sharply $(P P)$

+ increase slightly $(P)$

= remain the same $(E)$

- fall slightly (M)

-- fall sharply $(M M)$

DK $(\mathrm{N})$

Hence $\mathrm{PP}+\mathrm{P}+\mathrm{E}+\mathrm{M}+\mathrm{MM}+\mathrm{N}=100$.

On the basis of the distribution of the various options for each question, aggregate balances are calculated for each question based on the proportions in each category. Balances are the difference between positive and negative answering options, measured as percentage points of total answers. The score is calculated as $\mathrm{B}=(\mathrm{PP}+1 / 2 \mathrm{P})-(1 / 2 \mathrm{M}+\mathrm{MM})$ which means the scores can vary between -100 and +100 .

Chart 6 for the UK plots the fear of unemployment rate and the unemployment rate itself over a longer time run. The UK fear series jumped sharply in April 2008, and the other two scores rose abruptly in May 2008. All suggested a sharp downturn in the second quarter of 2008, which is the month where the recession started based on two successive negative growth quarters.

${ }^{20}$ https://www.markiteconomics.com/Public/Release/PressReleases 
The fear of unemployment started picking up from March 2005 (=14.7) and rose steadily through November 2006 (34) and then fell back through July 2007 (25.5). The unemployment rate started rising from 4.5\% in August 2005 to 5.5\% in January 2007 before falling back to 5.2\% in February 2008. The movements of the fear of unemployment preceded the changes in the unemployment rate. From September 2007 the fear series started picking up reaching a peak in January 2009. The unemployment rate started rising in March 2008, reaching a peak in September 2009. In August 2008 the fear series reached 49.8; the previous time it reached that level was when the unemployment rate was over $10 \%$.

Of note also is that the fear of unemployment series in the UK started picking up from 2014 even as the unemployment rate continued to fall through September 2019 before starting to pick up before the pandemic hit. Single month unemployment rates went from 3.5\% in October 2019, rising to $4.0 \%$ in January 2021 . It should also be noted that not only had the unemployment rate started to rise pre-pandemic, but quarterly GDP growth had also started to slow with the latest estimate for 2019Q4 of $0 \%$.

Many other qualitative indicators in the UK were flashing red by the second quarter of 2008 and were approaching or even passing historic lows. Chart 7 plots the Bank of England Agents' Scores on recruitment difficulties. Prior to 2008 the lowest level the series had reached was -0.7 in August 2006. The series started declining from the start of 2008.

Jan-08=0.9; Feb-08=0.6; Mar-08=0.3; Apr-08=0.1; May-08=-0.2; Jun-08=-0.7; Jul-08=-1.1; Aug08=-1.3; Sep-08=-1.8; Oct-08=-2.2; Nov-08=-2.7; Dec-08=-3.1; Jan-09=-3.2; Feb-09=-3.4; Mar$09=-3.5$.

The series had gone negative in May 2008 and at -1.1 was below its historic low when the MPC in August 2008 declared there was no recession. Chart 8 plots Markit's Employment PMI and shows that the previous low of the series was 45.6 in December 2001; that number was reached in July 2008 and the series continued down.

Jan-08=51.3; Feb-08=51.3; Mar-08=51.9; Apr-08=50.7; May-08=46.8; Jun-08=46.9; Jul08=45.6; Aug-08=46.5; Sep-08=45.3; Oct-08=44.3; Nov-08=41.1; Dec-08=38.9; Jan-09=38.5; Feb-09=38.3; Mar-09=38.0.

Both series suggests the UK was slowing sharply, and presumably in recession, having reached historic lows certainly by July 2008. This was apparent in July 2008.

\subsection{Other qualitative surveys}

Table 5 reports results by sector from the same source as the fear of unemployment series for the period January 2007 to May 2009. Here we report confidence series by four business sectors and for the consumer. Together they are aggregated to calculate the Economic Sentiment Index. ${ }^{21}$ Each is an aggregation of several components. Details are provided in the notes to the table. We also report pre-2007 averages. It is notable that all five series started declining in 2007.

\footnotetext{
${ }^{21}$ https://ec.europa.eu/info/files/user-guide-joint-harmonised-eu-programme-business-and-consumer-surveys_en
} 
In the case of manufacturing the index started deteriorating in March 2008 and went below its long run average (-7.7) in May 2008. Similarly, Construction started declining in November 2007 also went below its long run average (-13.2) in May 2008. The other three sectors all went below their long run averages at the end of 2007. Services went below the long run average in November 2007 while retail and the consumer indices went below those averages in December. By August 2008 when the MPC said there would be no recession the Service score of -22.1 was below its historic low of -17.6 , as were both the Consumer (-25.6 versus -25.3$)$ and Retail scores (-26.5 versus -22.4).

\subsection{The Bank of England missed the Great Recession}

When setting interest rates, for example, the problem is not only trying to understand where the economy is going but also, as noted above, where the economy has been and where it is at that time. Time lags in data releases on the labor market are also problematic especially in the UK, where data releases are delayed more than in any other country. ${ }^{22}$

In its August 2008 Inflation Report (IR) the MPC forecast no recession: "the Committee's central projection is for GDP to be broadly flat over the next year or so" (p.37). Indeed, the word 'recession" is nowhere to be found in the report. It seems the MPC spotted, but ignored, the rapid decline in both the Nationwide and EU surveys of household's expectations of employment as shown in Chart 9 (IR Chart 3.8). The MPC also reported that the percentage growth of LFS employment had slowed from 0.5\% in Q407; to 0.4\% in Q108; 0.3\% in Apr08 and 0.2\% in May08. Plus, hours of work growth had halved between Q108 and April and May08. (IR table 3.8) while vacancies had collapsed (IR chart 3.7). The evidence of slowing was blindingly obvious as was pointed out in Blanchflower (2008).

The latest data on the labor market available from the ONS, now available from the National Archive, reported on $16^{\text {th }}$ April 2008 showed an unemployment rate for December 2007-February 2008 of $5.2 \%{ }^{23}$ The main headline in the report is that it was down $0.1 \%$ compared with the three months September-November 2007. Blanchflower (2008) however, did note on the basis of this release, that there were broad signs of the UK labor market starting to slow. ${ }^{24}$ The signs included the following:

1) Hourly earnings growth is sluggish - both the AEI and LFS measures are slowing.

2) Total hours and average hours started to fall in early 2008.

3) Claimant count numbers for February 2008 are revised up from a small decline to an increase.

4) There is a growth in the number of part-timers who say they have had to take a full-time job because they couldn't find a part-time job - up 37,000 in March alone.

\footnotetext{
${ }^{22}$ In contrast, the BLS reported data for the US unemployment rate of 5.0\% for April 2008 on Friday May $2^{\text {nd }} 2008$ https://www.bls.gov/news.release/archives/empsit_05022008.htm

${ }^{23}$ https://webarchive.nationalarchives.gov.uk/ukgwa/20111122125222/http://www.ons.gov.uk/ons/rel//ms/labormarket-statistics/april-2008/index.html

https://webarchive.nationalarchives.gov.uk/ukgwa/20111122125154/http://www.ons.gov.uk/ons/rel/lms/labormarket-statistics/august-2008/index.html

${ }^{24}$ This paper has been downloadable from the Bank of England's website since 29 ${ }^{\text {th }}$ April 2008.
} 
5) Even though the number of unemployed has fallen, the duration of unemployment appears to be rising, which means that the outflow rate from unemployment has fallen. The numbers unemployed over 6 months in March 2008 was up 22,000 while the numbers unemployed for less than 6 months was down 47,000.

6) As in the United States, recent declines in employment in the UK, Blanchflower noted, were concentrated in manufacturing, construction and financial activities. The numbers presented below are in thousands, seasonally adjusted and relate to the number of workforce jobs. The quarterly data relate to the period September-December 2007 while the annual data refer to December 2006-December 2007.

All jobs

Manufacturing

Construction

Finance \& Business Services

\section{Change on quarter}

$+13(0.0 \%)$

$-29(-0.9 \%)$

$-19(-0.9 \%)$

$-5(-0.1 \%)$

$$
\begin{gathered}
\text { Change on year } \\
+208(0.7 \%) \\
-53(-1.6 \%) \\
-7(-0.3 \%) \\
+149(2.3 \%)
\end{gathered}
$$

It was clear that the UK labor market in April 2008 was slowing fairly quickly but it took several months to show up in the data. In the $13^{\text {th }}$, August 2008 Labor Market Release from the ONS, which provided evidence for April-June 2008, much had changed, and the unemployment rate had now jumped to $5.4 \%$. By the $15^{\text {th }}$, October 2008 release, the unemployment rate for June-August had reached 5.7\%. The subsequent rises were reported in Table 4 below which showed that employment started declining in May 2008.

The August release seasonally adjusted employment for those age 16+ for Apr-Jun 2008 was reported from the Labor Force Survey as 29,558,000, up from 29,541,000 in March-May 2008. However, the ONS subsequently adjusted the population weights and now the two numbers have been revised, as shown in Table 4, to show a fall of employment of 27,000 between April and May 2008. See for example Palmer and Chandler (2008) and Chandler (2009) and especially ONS (2014) that revised the May-July 2008 estimate to be consistent with the 2011 Census.

Blanchflower (2008) also looked at qualitative indicators that were available at the end of April 2008 as an alternative and these are reported in Appendix Table 5. Many were at historic lows. They have not been revised. The table reports on five qualitative indicators showing what was known at the time at the end of April 2008. In part a) there are four consumer confidence indicators, along with their long-run averages, one from Nationwide and three from GFK with an overall balance, indictors of views of the future economic situation and views on major purchases. All four started dropping sharply at the end of 2007.

By March 2008, which was the most recent data available in April 2008, all four were well below their long run historical averages. For example, the Nationwide Consumer Confidence Index stood at 77 compared to a series average of 96, and down from 110 in January 2005. Part b) of Appendix Table 5 reports on changes in a qualitative labor market series from REC on the demand for staff. This series started tumbling rapidly from around July 2007 and was at 49.0 in February 2008, compared with 64.1 in July 2007. All were good predictors of what was to come. 
By the Spring of 2008 it was apparent from a large variety of UK qualitative data series, from the Nationwide Consumer Confidence series, The REC Series on demand for staff, the Bank of England Agents, the PMIs and the EU Commission Business and Consumer Surveys, all of which were saying the same things. The UK had followed the US into recession. It turns out, using the data in Table 1, that by the start of Q32008 another 22 OCED countries had also entered recession, but neither the MPC, the FOMC or the ECB to name but a few seemed to notice. It was possible to spot the recession coming across the OECD, including in the US and the UK.

\section{The rest of the OECD}

In most OECD countries the unemployment rate took somewhat longer to respond than it did in the United States where the Great Recession started. The monthly unemployment rates for these countries are reported in Appendix Table 1 from December 2007 through April 2009. Annual rates are reported in Appendix Table 6 and annual changes in employment are reported in Appendix Table 7. In Germany and the Netherlands, the unemployment rate fell steadily through October 2008, before rising. In France it started rising from June 2008, while in Italy the rise started in April 2008. In Spain and Greece, the rate started rising from November 2007. In the UK, the first big jump, from 5.2\% to 5.4\% was between April and May 2008. ${ }^{25}$

We then obtained monthly unemployment rates across 40 OECD countries and estimated the Sahm Rule. The full excel data file is available on request from the authors. The first column of Table 6 reports what we found, ranked by date, derived using the data in Appendix Table 1. We report Q32008 for New Zealand as they only publish quarterly data. ${ }^{26}$ Sixteen of the estimates are for 2009, including five of the countries that did not have two successive negative GDP quarters Australia, Bulgaria, South Korea, Malta, Poland and Slovakia. For the remaining eleven this is well after recession is indicated by the GDP data. The Sahm Rule for Canada identifies the start of recession as December 2008, consistent with the GDP data which suggests Q42008.

Even for those countries with Sahm Rule estimates in 2008 most are later than would be indicated by the GDP data. For example, the GDP data suggest that the recession started in France (Dec08), Germany (Apr-09), Italy (Feb-08), Japan (Feb-09) and the UK (Aug-08) in the second quarter of 2008 with the Sahm date in parentheses. The GDP data looks a better indicator of recession, but the problem is that these are estimates more than a decade later that have been subject to revision. These numbers were generally not available in 2007 and 2008.

\section{Predicting turning points}

The big question is, was this all foreseeable before it happened? Should the MPC and other central banks like the ECB have spotted it? Were the data there? It turns out they were. Hence, we now

\footnotetext{
${ }^{25}$ Appendix Table 7 shows annual employment changes from 2006 across OECD countries. Of particular note is that only a few countries besides the USA saw declines in 2008 compared with 2007; the major examples are Japan (280k) and Spain (-110k). With only a few exceptions employment declined in 2009 versus 2008; the main exceptions are Mexico (+492k); and Brazil (+425k). The picture was more mixed in 2010 versus 2009, with the US still experiencing decline (-813k) but there was job growth in Australia (+217k); Canada $(+222 \mathrm{k})$; Chile $(+350 \mathrm{k})$; Germany $(+255 k)$; Korea $(+345 k)$ and Turkey $(+1315 k)$. Japan saw a major fall in employment in $2011(-2820 k)$ and so to a lesser extent did Greece (-335k) and Portugal (-158k). The UK only saw job loss in 2009 (-430k).

${ }^{26}$ Unemployment rates for New Zealand are Q407=3.4\%; Q108=3.8\%; Q208=3.8\%; Q308=4.1\%; Q408=4.4\%; $\mathrm{Q} 109=5.0 \%$ and Q209=5.8\%
} 
turn to Table 7 where we report the consumer fear of unemployment data by month from January 2007 through June 2008 for twenty-nine European countries including Turkey. We identify the month in 2007 when the fear series reached its minimum and identify that in red. We then identify when the fear series had risen by ten fear points versus the low point in 2007. We think of this as a potential alternative 'rule' to the Sahm Rule.

Another possibility to the plus 10 Rule is to identify when scores rise above the long run pre 2008 average. With the exception of Hungary, Portugal and the UK all of these starting points are below their long run averages. Using this rule we report in column 2 of Table 6, the month identified in the table using the plus 10 rule. Almost all of these are well before the Sahm rule dates in column 1 and none are in 2009, whereas sixteen countries according to the Sahm Rule are.

The plus 10 rule works well in Europe. In 24/28 countries the start date of the recession identified by the plus 10 rule comes before the first of two quarters of negative GDP growth reported in column 3 of Table 6 . The exceptions are fairly close. We miss four: 1) Italy where we identify July08 as the turn whereas GDP suggests Apr-08 2) Luxembourg where we identify Sept-08, and GDP suggests Jan-08, 3) Hungary and Slovenia where we identify Oct08 whereas GDP dropped first in Jul-08. The start as measured by the first of two negative GDP quarters comes before the Sahm rule date in 17/28 countries. Four are the same - Belgium, Bulgaria, Lithuania, and Slovakia. The Sahm Rule precedes that determined by GDP in five countries - Hungary, Ireland, Italy, Latvia, Spain

Results are very similar if we simply look to see evidence of big monthly increases without imposing a rule. Another possibility is to look for large upward monthly changes. Examples in western Europe from Table 7 are: Austria Oct-08(+13); Belgium Jul-08 (+9); Denmark Apr-08 (+8); Finland Feb-08 (+9); France Jul-08 (+9); Germany Aug-07 (+12); Ireland Feb-07 (+15); Italy Jul-08(+9); Netherlands Sep-07 (+7); Portugal Mar07 (+7); Spain Sep07 (+13); Malta Apr07 $(+12)$; Sweden Feb-08 (+9) and UK Jul-08 (+10). In Eastern Europe from the third part of Table 7 there are some even larger monthly jumps of nearly fifty; Bulgaria Oct-08 $(+11)$; Croatia Dec08 (+15); Czechia Oct-08 (+25); Estonia May-08 (+11); Latvia Apr-08 (+11); Lithuania Oct-08 $(+1$; Hungary Oct08 (+21); Poland Nov08 (+10); Romania Nov-08 (+34); Slovenia Nov-08 (+35.8); Slovakia Nov-08 (+49) and Turkey Feb-08 (+11). These give broadly similar results to our rule we adopted for simplicity.

If we look at Table 5 which has the four business and one consumer indicators for the UK from January 2007 to May 2009, we can also use the plus 10 rule. In that case we see all give recession start dates from the end of 2007 through May 2008.

$\begin{array}{lll} & \text { High in 2007 } & \text { Month }+10 \\ \text { Industry } & \text { September 2007 } & \text { May 2008 } \\ \text { Services } & \text { May 2007 } & \text { November 2007 } \\ \text { Consumer } & \text { August 2007 } & \text { December 2007 } \\ \text { Retail } & \text { April 2007 } & \text { December 2007 } \\ \text { Construction } & \text { October 2007 } & \text { May 2008. }\end{array}$


The Sahm Rule dates mostly come after those identified using the fear data either using the 10plus rule or looking for big monthly changes. These dates are also after those identified using GDP in seventeen countries including most of the major Western countries - Austria, Croatia, Czechia, Cyprus, Denmark, Estonia, Finland, France, Germany, Greece, Luxembourg, Netherlands, Portugal, Romania, Slovenia, Turkey and the UK.

Returning to the US there is one suitable employment confidence survey series available to calculate the plus 10, rule. The Conference Board's Plentiful Jobs Index as reported in Blanchflower (2008, Appendix Table 1) can be used. ${ }^{27}$ The highest value in 2007 was in March at 30.7. It took until March 2008 for the series to drop at least 10 points to 18.5. The $10+$ rule appears to also work in the United States. We knew this in March 2008.

\section{Conclusions}

This paper examines various data series for the United States, the UK and the rest of the OECD and considers how movements in these data helped identify the onset of the Great Recession. For the majority of OECD countries, it is feasible to identify the start of the Great Recession using the rule of two successive negative quarters of GDP growth. We found this in 32 of the 39 countries we examined. Of these only three saw the recession start in 2007, while the rest started in 2008. However, we only know this more than a dozen years after the onset of recession due to data revisions. At the time GDP estimates tended to overestimate GDP growth. Thus, a major problem with using these data is that it may well take a while to find the true turning point. This was the case in the UK when it took until June 2009 to establish that the recession started in April 2008.

The United States is in a unique position as it has the NBER Business Cycle Dating Committee who do not mechanically call recessions based on the two negative quarter GDP rule. In December 2008 the NBER called the start of recession as December 2007 despite the fact that there is a good deal of evidence from state level employment data suggesting the start was around July 2008. The reason for this was mostly based on developments in the labor market, including declining employment and rising unemployment. Unlike in the US, most other countries saw labor market declines coming after two negative quarters (e.g. France, Germany, Japan and the UK). This is what appears to have happened too in the pandemic when US unemployment rose sharply during 2020 but did so much less in other OECD countries.

We then evaluated the Sahm Rule which has been suggested as a way of signaling recession based on looking at the unemployment rate. It indicates recession started in February 2008. We applied this to 39 other countries and found that more often than not the start date was later than that derived from using GDP. But that is an ex-post rationalization, given that we know that at turning points GDP data itself is revised down and the Sahm Rule can indicate what is coming.

Evidence of employment declines across US states using household data suggests that recession started in 2007. By August 2007 thirty-eight states and the US as a whole had seen at least two

\footnotetext{
27 Its values are Jan-06=27.0; Feb-06=27.4; Mar-06=28.3; Apr-06=29.4; May-06=29.1; Jun-06=28.0; Jul-06=28.6; Aug-06=24.5; Sep-06=26.2; Oct-06=25.6; Nov-06=25.7; Dec-06=27.6; Jan-07=29.6; Feb-07=27.8; Mar-07=30.3; Apr-07=29; May-07=29.1; Jun-07=27.6; Jul-07=30; Aug-07=27.5; Sep-07=25.6; Oct-07=24.1; Nov-07=23.3; Dec07=23.6; Jan-08=23.8; Feb-08=21.5; and Mar-08=18.8.
} 
successive quarters of negative growth in 2007. Non-farm payrolls declines suggest February 2008.

The major point of this paper is to argue that the qualitative data are the best indicators of recession across the OECD. In the US the labor market data turned down before quarterly GDP did. The reverse is true in other OECD countries. But in all of these countries qualitative data had turned down earlier, and especially so in the United States. Policymakers should focus on the qualitative data as an indicator of turning points. We find a good measure of when the recession started is when the fear of unemployment series begins to rise sharply. We adopt a "10 point rule": recession is signaled when the fear of unemployment series rose 10 points above its 2007 low. We use this rule as the data series had started to rise early in some countries such as the UK and the mean of the pre 2007 series differs a lot by country. It is especially low for example, in Denmark, Finland and Sweden, which are well known to be the happiest countries in the world (Blanchflower and Oswald, 2011).

We found this rule helped predict GDP calculated recession across the 28 countries we examined. In eleven countries the spike was in 2007 and unlike the Sahm Rule none was in 2009. In five countries it was in the same quarter as suggested using GDP (Belgium; Cyprus; Finland, Romania and the UK). In seventeen it was in an earlier quarter (Austria, Bulgaria, Croatia, Czechia, Denmark, Estonia, France, Germany, Greece, Ireland. Latvia, Lithuania, Netherlands, Portugal, Slovakia, Spain and Turkey). In three it was in the following quarter (Hungary, Italy and Slovenia) while in Luxembourg it was two quarters later. In two countries that GDP did not identify a recession we found the recession started in Poland in July 2008 and in Malta in April 2007, compared with February 2009 for both using the Sahm Rule.

The qualitative data were flashing red for recession across the OECD by April of 2008. Later GDP data confirmed that fact. It was also apparent that what was happening in the US had spread around the world as it did in the 1929 Great Crash. The data showed clearly by the spring of 2008 that the US had been in recession for several months (Blanchflower, 2008). This should have suggested the rest of the advanced world as going to follow a financial crisis in the US given the global banking system. Almost everywhere, and certainly in all the major Western countries, all of the qualitative data series we looked at were tumbling by the Spring of 2008. That was true by country and also true in manufacturing, services, retail and construction and consumer confidence was also plunging.

It turned out though that a big difference was that it took a while for the unemployment rate in particular to pick up outside the United States, just as happened in the Spring of 2020 as the COVID lockdown was implemented. Sadly, even by the time Lehman Brothers failed on September $14^{\text {th }}, 2008$, central bankers, policymakers and most economists hadn't understood what was happening on the ground. It was there right in front of their very eyes in the qualitative data, but they failed to look. This paper suggests this would not have happened in Europe if they had implemented the Plus 10 Rule. The moral from this is there was sufficient data available in early 2008 such that policymakers should have been able to predict the timing and scale of these sorts of events with quite a lot of precision. 
Bank of England (2008), Inflation Report, August.

\section{References}

Bell, D.N.F. and D.G. Blanchflower (2021). 'Underemployment in the United States and Europe', Industrial and Labor Relations Review, 74(1), pp. 56-94.

Blanchflower, D.G. and A.J. Oswald (2011), 'International happiness: a new view on the measure of performance', Academy of Management Perspectives, 2(1), pp. 6-22.

Blanchflower, D.G. (2008), 'Inflation expectations and monetary policy', speech given at the Royal Society, Edinburgh, 29 April 2008, Bank of England. https:/www.bankofengland.co.uk//media/boe/files/speech/2008/inflation-expectations-and-monetary-policy

Blanchflower, D.G. (1991), 'Fear, unemployment and pay flexibility', The Economic Journal, May; 483-496.

Blanchflower, D.G. and A.J. Bryson (2021), 'The economics of walking about and predicting unemployment’, NBER Working Paper 29172.

Blanchflower, D.G. and C. Shadforth (2009), 'Fear, unemployment and migration', The Economic Journal, 119(535), February, F136-F182.

Chandler, M. (2009), 'Labor Force Survey: Interim reweighting and annual review of seasonal adjustment, 2009’, Economic \& Labor Market Review, 3(12), December, pp. 56-61.

Feng, S. and J. Sun (2021), 'Misclassification-errors-adjusted Sahm rule for early identification of economic recession’, Journal of Asian Economics, Volume 75, August 2021, 101319

Knowlton, C. (2021), Bubble in the Sun: The Florida Boom of the 1920s and How It Brought on the Great Depression, Simon and Schuster.

Palmer, N. and M. Chandler (2008), 'Labor Force Survey: interim reweighting 2008', Economic \& Labor Market Review, 2(11), November, pp. 56-61.

Office for National Statistics (2014), '2011 Census-based reweighting of Labor Force Survey estimates: indicative historical revisions, mid-2001 to end 2013’, 23 September 2014

Sahm, C. (2019), 'Direct stimulus payments to individuals’, Brookings, Thursday, May 16. 
Table 1. Quarterly GDP growth, Q42007-Q12009.

$\begin{array}{lcccrrr}\text { Location } & \text { Q4-2007 } & \text { Q1-2008 } & \text { Q2-2008 } & \text { Q3-2008 } & \text { Q4-2008 } & \text { Q1-2009 } \\ \text { Australia } & 0.5 & 1.1 & 0.2 & 0.7 & -0.4 & 1.0 \\ \text { Austria } & 0.8 & 0.5 & 1.0 & -0.6 & -2.3 & -1.8 \\ \text { Belgium } & 0.4 & 0.4 & 0.1 & -0.6 & -2.2 & -1.0 \\ \text { Bulgaria } & 2.1 & 1.7 & 1.1 & 1.0 & 0.3 & -3.9 \\ \text { Canada } & 0.1 & 0.1 & 0.4 & 0.8 & -1.2 & -2.3 \\ \text { Chile } & 1.7 & 2.6 & 0.1 & -0.8 & -1.0 & -0.8 \\ \text { Czech Republic } & 1.2 & 0.5 & 0.7 & 0.2 & -1.8 & -3.4 \\ \text { Denmark } & 1.0 & 0 & -0.9 & -0.6 & -2.4 & -1.4 \\ \text { Estonia } & -0.6 & -2.2 & 1.0 & 0.1 & -11.7 & -2.6 \\ \text { Finland } & 1.3 & -0.1 & -0.8 & 0.3 & -2.1 & -6.5 \\ \text { France } & 0.2 & 0.4 & -0.4 & -0.3 & -1.4 & -1.7 \\ \text { Germany } & 0.7 & 0.6 & -0.2 & -0.6 & -1.6 & -4.7 \\ \text { Greece } & -0.5 & 0.6 & -0.6 & -0.1 & -1.4 & -4.7 \\ \text { Hungary } & 0.4 & 1.0 & 0.6 & -0.2 & -3.3 & -4.3 \\ \text { Iceland } & 4.6 & -2.9 & 3.6 & -5.6 & 6.0 & -10.7 \\ \text { Ireland } & 3.9 & -2.9 & -2.6 & -0.3 & -4.3 & 0.2 \\ \text { Israel } & 1.5 & 0.8 & 0.2 & 0.2 & -0.8 & -0.1 \\ \text { Italy } & -0.3 & 1.1 & -0.9 & -1.2 & -2.5 & -2.8 \\ \text { Japan } & 0.4 & 0.4 & -0.6 & -1.2 & -2.5 & -4.8 \\ \text { Korea } & 2.2 & 0.4 & 0.5 & 0.8 & -3.3 & 0.1 \\ \text { Latvia } & -1.2 & 1.9 & -3.5 & -4.1 & -2.4 & -3.7 \\ \text { Lithuania } & 1.7 & -0.5 & 0.7 & -1.2 & -0.8 & -12.9 \\ \text { Luxembourg } & 0.2 & -0.4 & -0.6 & -0.9 & -3.2 & -1.4 \\ \text { Malta } & -0.9 & 3.0 & 0.8 & 0.2 & 0.9 & -3.4 \\ \text { Mexico } & 0.4 & -0.2 & 0.7 & 0.3 & -1.6 & -5.1 \\ \text { Netherlands } & 1.4 & 0.3 & 0.5 & -0.1 & -0.7 & -3.6 \\ \text { New Zealand } & 0.2 & -0.3 & -0.3 & -0.4 & -0.7 & -1.0 \\ \text { Norway } & 1.1 & -1.3 & 0 & -0.2 & 0.3 & -0.8 \\ \text { Poland } & 1.3 & 1.9 & 0.2 & -0.3 & 0.4 & 1.6 \\ \text { Portugal } & 1.1 & 0 & -0.5 & -0.1 & -1.3 & -2.5 \\ \text { Romania } & 3.3 & 4.7 & 1.7 & 0.2 & -1.7 & -4.1 \\ \text { Russia } & 3.2 & 2.7 & 0.6 & -1.5 & -3.3 & -3.5 \\ \text { Slovak Republic } & 6.4 & -2.8 & 1.2 & 1.4 & 1.2 & -9.5 \\ \text { Slovenia } & 0.2 & 1.6 & 1.7 & -0.6 & -3.7 & -4.4 \\ \text { Spain } & 0.6 & 0.2 & 0.1 & -0.2 & -1.6 & -2.6 \\ \text { Sweden } & 1.1 & -0.7 & -0.1 & -0.5 & -3.6 & -1.4 \\ \text { Switzerland } & 1.1 & 0.9 & 0.9 & 0.4 & -2.8 & -1.6 \\ \text { United Kingdom } & 0.5 & 0.5 & -0.6 & -1.6 & -2.1 & -1.7 \\ \text { United States } & 0.6 & -0.4 & 0.6 & -0.5 & -2.2 & -1.2 \\ & & & & & & \end{array}$

Source: OECD and Eurostat.

Red shows negative GDP growth in countries that did not have two negative quarters. Green shows the two successive negative quarters. 
Table 2. Monthly changes in US employment in thousands

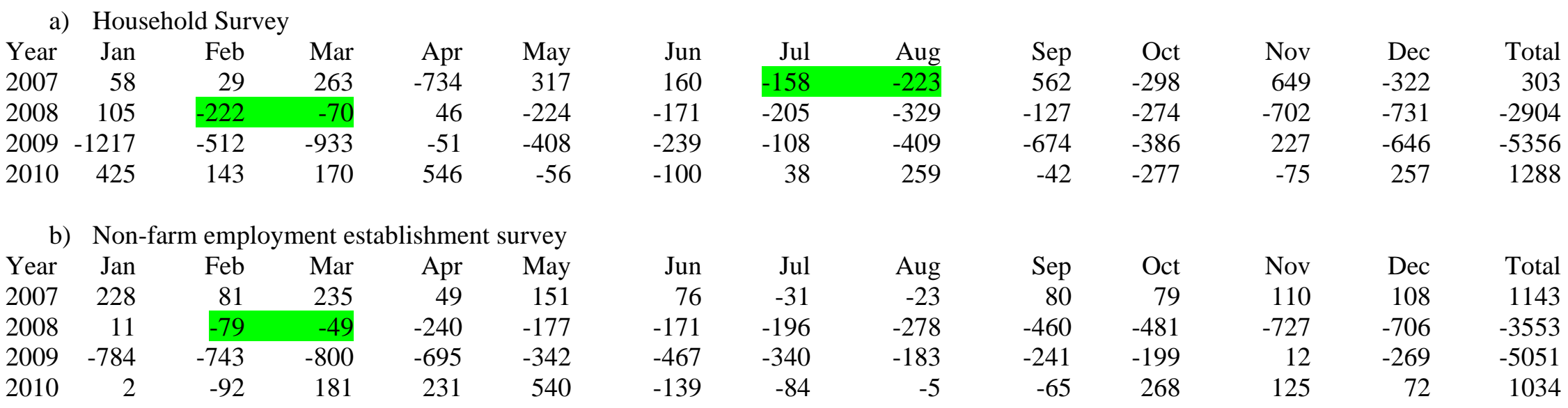

Notes: For details of the surveys see the Employment Situation, published monthly by the BLS. 
Table 3. Sahm Rule hits .5 versus monthly changes in employment ('000s)

a) Non-farm payrolls (NFP)

\begin{tabular}{|c|c|c|c|c|c|c|c|c|c|c|c|c|c|}
\hline Month & Nov-53 & Oct-57 & Nov-59 & Oct-60 & Mar-70 & Jul-74 & Feb-80 & Nov-81 & Oct-90 & Jun-01 & Nov-02 & Feb-08 & Apr-20 \\
\hline$t-5$ & 29 & -88 & 131 & -338 & 207 & 154 & 27 & 194 & 42 & -11 & 50 & 80 & 234 \\
\hline$t-4$ & 17 & -83 & 123 & -127 & -35 & 42 & 154 & 111 & 153 & 91 & -94 & 79 & 161 \\
\hline$t-3$ & -47 & 56 & -468 & -42 & 155 & 86 & 92 & -36 & 17 & -42 & -3 & 110 & 315 \\
\hline$t-2$ & -121 & 5 & 92 & -34 & -65 & 167 & 99 & -88 & -32 & -284 & -86 & 108 & 289 \\
\hline$t-1$ & -128 & -194 & -70 & -45 & 129 & 55 & 128 & -97 & -208 & -53 & 127 & 11 & -1683 \\
\hline & -332 & -171 & 276 & -85 & 146 & 32 & 83 & -209 & -98 & -111 & -13 & -79 & -20679 \\
\hline 1 & -205 & -205 & 540 & -181 & -103 & -17 & 111 & -276 & -151 & -122 & -143 & -49 & 2833 \\
\hline ? & -234 & -174 & 100 & -219 & -224 & -9 & -145 & -330 & -153 & -149 & 108 & -240 & 4846 \\
\hline+3 & -87 & -308 & 239 & -59 & -95 & 20 & -429 & -2 & -48 & -257 & -136 & -177 & 1726 \\
\hline
\end{tabular}

b) Household employment from the CPS

\begin{tabular}{|c|c|c|c|c|c|c|c|c|c|c|c|c|}
\hline Month Nov-53 & Oct-57 & Nov-59 & Oct-60 & Mar-70 & Jul-74 & Feb-80 & Nov-81 & Oct-90 & Jun-01. & Nov-02 & Feb-08 & Apr-20 \\
\hline $\begin{array}{ll}\mathrm{t}-5 & 437\end{array}$ & -62 & 150 & 98 & 195 & 154 & 564 & -750 & 299 & 164 & -124 & 562 & 184 \\
\hline-59 & 211 & 162 & 111 & 96 & 199 & 64 & 395 & -168 & -166 & -2 & -298 & 195 \\
\hline-246 & 344 & -167 & -259 & 199 & 65 & 170 & -4 & -173 & 171 & 292 & 649 & -76 \\
\hline-245 & -581 & -74 & -14 & 40 & -150 & 359 & -625 & -8 & -484 & 597 & -322 & 73 \\
\hline-13 & 162 & 141 & 372 & -82 & 222 & -54 & 314 & -278 & -207 & -294 & 105 & -3196 \\
\hline-155 & -75 & -381 & -635 & 165 & 50 & 116 & -171 & 12 & -219 & -487 & -222 & -22166 \\
\hline-761 & -377 & 811 & 477 & 67 & 208 & -282 & -562 & -230 & 198 & -95 & -70 & 3854 \\
\hline 47 & 253 & 6 & -331 & -366 & -112 & -480 & 47 & -65 & -830 & 991 & 46 & 4876 \\
\hline 639 & -702 & 273 & -2 & -151 & 14 & -288 & 70 & -301 & 605 & 65 & -224 & 1677 \\
\hline
\end{tabular}


Table 4. Monthly UK, Employment levels and changes '000s and the unemployment rate

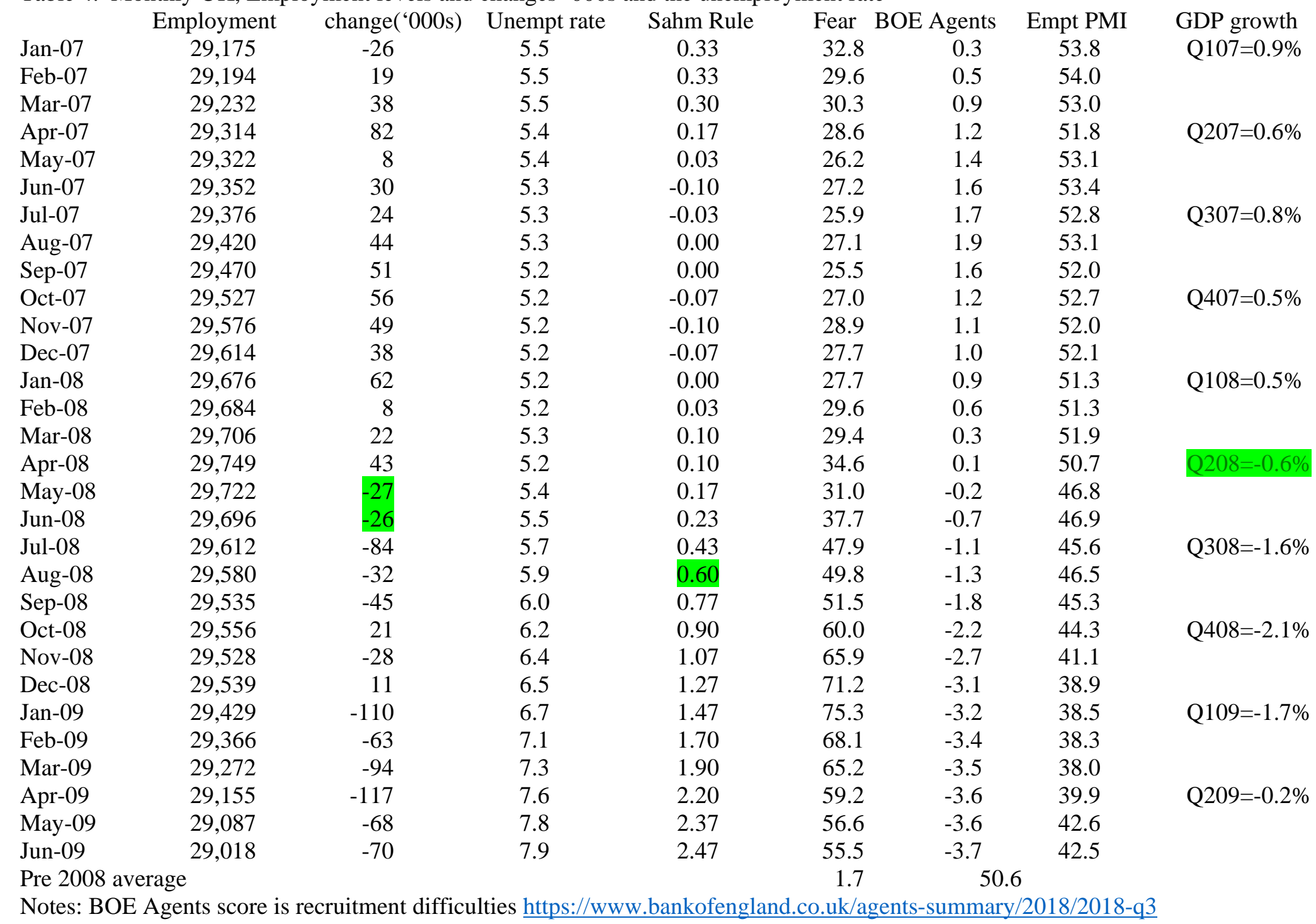


Table 5. Business and Consumer Sentiment Scores for the UK from EU Commission

\begin{tabular}{|c|c|c|c|c|c|}
\hline & Industry & Services & Consumer & Retail & Construction \\
\hline Jan-07 & 0.5 & 16.7 & -9.0 & 12.7 & 0.1 \\
\hline Feb-07 & 3.2 & 14.0 & -7.5 & 15.5 & -0.4 \\
\hline Mar-07 & 5.8 & 16.2 & -7.4 & 20.1 & -0.3 \\
\hline Apr-07 & 1.9 & 11.4 & -6.9 & 21.8 & 0.9 \\
\hline May-07 & 4.5 & 18.1 & -3.8 & 17.5 & -1.7 \\
\hline Jun-07 & 9.0 & 14.7 & -4.8 & 6.8 & -2.7 \\
\hline Jul-07 & -1.0 & 8.3 & -5.6 & 6.6 & 2.0 \\
\hline Aug-07 & -1.3 & 12.4 & -4.4 & 15.6 & 1.9 \\
\hline Sep-07 & 4.2 & 16.2 & -4.9 & 8.5 & 2.7 \\
\hline Oct-07 & 3.5 & 13.0 & -4.4 & 11.1 & 5.5 \\
\hline Nov-07 & 2.2 & 6.0 & -7.2 & 10.0 & -1.3 \\
\hline Dec-07 & 0.0 & 9.2 & -7.7 & -4.7 & -0.3 \\
\hline Jan-08 & 5.8 & -2.7 & -8.3 & -4.7 & -0.3 \\
\hline Feb-08 & -4.2 & -16.9 & -10.5 & 1.6 & -0.6 \\
\hline Mar-08 & 2.0 & 0.8 & -11.6 & 5.1 & -0.2 \\
\hline Apr-08 & -7.4 & -4.7 & -17.2 & -9.7 & -8.6 \\
\hline Мay-08 & -12.3 & -12.6 & -19.7 & -6.8 & -25.2 \\
\hline Jun-08 & -6.9 & -12.9 & -23.8 & -11.6 & -32.2 \\
\hline Jul-08 & -11.4 & -15.5 & -28.8 & -22.4 & -37.2 \\
\hline Aug-08 & -15.7 & -22.1 & -25.6 & -26.5 & -39.4 \\
\hline Sep-08 & -21.2 & -18.8 & -24.2 & -29.3 & -43.1 \\
\hline Oct-08 & -30.2 & -28.8 & -25.5 & -35.0 & -48.0 \\
\hline Nov-08 & -28.3 & -35.2 & -24.7 & -39.1 & -52.9 \\
\hline Dec-08 & -32.6 & -41.0 & -25.3 & -45.1 & -58.2 \\
\hline Jan-09 & -35.6 & -48.9 & -30.1 & -47.1 & -63.5 \\
\hline Feb-09 & -44.9 & -48.9 & -27.7 & -44.2 & -66.9 \\
\hline Mar-09 & -49.0 & -57.4 & -23.9 & -39.8 & -55.5 \\
\hline Apr-09 & -43.3 & -50.4 & -20.5 & -28.1 & -55.0 \\
\hline May-09 & -39.6 & -42.0 & -20.5 & -20.2 & -56.0 \\
\hline Pre 06 avge & -7.7 & 12.4 & -7.0 & 4.7 & -13.1 \\
\hline
\end{tabular}

Red shows the highest value in 2007 and the green shows when the series dropped ten pints.

a) Industry

COF Confidence Indicator (Q2 - Q4 + Q5) / 3

Q2. Assessment of order-book levels

Q4. Assessment of stocks of finished products

Q5. Production expectations for the months ahead

b) Services

COF Confidence Indicator (Q1 + Q2 + Q3) / 3

Q1. Business situation development over the past 3 months

Q2. Evolution of the demand over the past 3 months

Q3. Expectation of the demand over the next 3 months

c) Retail

COF Confidence Indicator (Q1 - Q2 + Q4) / 3

Q1. Business activity (sales) development over the past 3 months

Q2. Volume of stock currently hold

Q4. Business activity expectations over the next 3 months 
d) Construction

COF Confidence Indicator (Q3 + Q4) / 2

Q3. Evolution of your current overall order books

Q4. Employment expectations over the next 3 months

e) Consumer

COF Confidence Indicator (Q1 + Q2 + Q4 + Q9) / 4

Q1. Financial situation over last 12 months

Q2. Financial situation over next 12 months

Q4. General economic situation over next 12 months

Q9. Major purchases over next 12 months

https://ec.europa.eu/info/business-economy-euro/indicators-statistics/economic-databases/business-andconsumer-surveys/download-business-and-consumer-survey-data/time-series_en

Green shows the month the score was 10 below its 2007 peak, marked in red. 
Table 6. Recession dates by Sahm Rule, Fear of Unemployment and two negative quarters GDP growth

Sahm Rule

Chile September 2007

Hungary

Ireland

Spain

Italy

Latvia

USA

Luxembourg

Iceland

Israel

Lithuania

New Zealand

Belgium

Denmark

Estonia

Turkey

UK

Finland

Mexico

Norway

Austria

France

Canada

Australia

Greece

Czechia

Portugal

Japan

Malta

Poland

Slovakia

Bulgaria

Cyprus

Russia

Slovenia

Croatia

Germany

Korea

Netherlands

Romania
December 2007

December 2007

December 2007

February 2008

February 2008

February 2008

April 2008

July 2008

July 2008

July 2008

Q32008

August 2008

August 2008

August 2008

August 2008

August 2008

November 2008

November 2008

November 2008

December 2008

December 2008

December 2008

January 2009

January 2009

January 2009

January 2009

February 2009

February 2009

February 2009

February 2009

March 2009

March 2009

March 2009

March 2009

April 2009

April 2009

May 2009

June 2009

April 2009
+10 Rule

October 2008

February 2007

September 2007

July 2008

January 2008

March 2008

September 2008

November 2007

July 2008

December 2007

July 2007

November 2007

June 2008

February 2008

June 2008

October 2007

November 2007

August 2008

January 2008

April 2007

July 2008

April 2007

October 2007

November 2008

October 2008

June 2008

August 2007

February 2008

November 2008
GDP

Q32008

Q32008

Q12008

Q32008

Q22008

Q22008

Q32008

Q12008

NR

Q42008

Q32008

Q12008

Q32008

Q22008

Q12008

Q22008

Q22008

Q12008

Q42008

NR

Q32008

Q22008

Q42008

NR

Q22008

Q42008

Q22008

Q22008

NR

NR

Q12009

Q12009

Q42008

Q32008

Q32008

Q32008

Q22008

NR

Q32008

Q42008

$\mathrm{NR}=$ no recession 
Table 7. Fear of unemployment by month, January 2007-June 2009 Western Europe.

\begin{tabular}{|c|c|c|c|c|c|c|c|c|}
\hline & Austria & Belgium & Cyprus & Denmark & Finland & France & Germany & Greece \\
\hline Jan-07 & -5.5 & 17.7 & 46.7 & -14.1 & -1.8 & 9.5 & 4.1 & 38.0 \\
\hline Feb-07 & -5.1 & 16.3 & 47.3 & -10.8 & 7.2 & 10.0 & 3.2 & 37.9 \\
\hline Mar-07 & -3.4 & 15.6 & 45.9 & -8.7 & 6.3 & 16.2 & 2.2 & 37.2 \\
\hline Apr-07 & -4.3 & 6.7 & 44.3 & -10.6 & -5.2 & 10.3 & -6.5 & 37.3 \\
\hline Маy-07 & -6.1 & 10.6 & 38.0 & -6.5 & -2.1 & -3.8 & -10.7 & 33.1 \\
\hline Jun-07 & -6.4 & 9.2 & 40.7 & -9.9 & -7.4 & -5.4 & -9.3 & 34.3 \\
\hline Jul-07 & -5.3 & 12.0 & 36.5 & -11.2 & -8.2 & -5.4 & -9.2 & 38.7 \\
\hline Aug-07 & -4.9 & 4.9 & 38.5 & -6.8 & -9.1 & -0.9 & 3.1 & 36.2 \\
\hline Sep-07 & -1.5 & 6.4 & 35.3 & -7.9 & -8.7 & 3.5 & 6.2 & 27.9 \\
\hline Oct-07 & 0.1 & 5.3 & 39.2 & -9.6 & -7.7 & 11.3 & 0.8 & 26.0 \\
\hline Nov-07 & 1.1 & 11.1 & 37.2 & -7.6 & 5.6 & 11.8 & 3.8 & 38.3 \\
\hline Dec-07 & 2.4 & 6.1 & 40.8 & 2.0 & 1.7 & 6.3 & 5.8 & 38.3 \\
\hline Jan-08 & 1.3 & 3.8 & 36.7 & 2.5 & 5.1 & 7.2 & 5.7 & 43.9 \\
\hline Feb-08 & 1.8 & 2.6 & 35.7 & 5.8 & 14.4 & 10.7 & 11.1 & 41.4 \\
\hline Mar-08 & 1.5 & -0.6 & 35.0 & 4.5 & 4.1 & 15.0 & 11.4 & 45.1 \\
\hline Apr-08 & -0.9 & 5.3 & 36.2 & 12.6 & 2.3 & 9.5 & 0.2 & 44.2 \\
\hline Мay-08 & 4.6 & 9.3 & 28.9 & 11.3 & 2.9 & 11.5 & 1.6 & 45.1 \\
\hline Jun-08 & 8.4 & 6.9 & 33.2 & 15.8 & 2.2 & 9.6 & 2.7 & 35.3 \\
\hline Jul-08 & 11.1 & 16.2 & 33.2 & 23.4 & 11.5 & 18.4 & 8.7 & 51.9 \\
\hline Aug-08 & 18.5 & 18.3 & 33.0 & 16.7 & 10.0 & 25.8 & 22.7 & 50.0 \\
\hline Sep-08 & 17.8 & 20.2 & 30.2 & 20.6 & 15.7 & 28.6 & 20.4 & 46.8 \\
\hline Oct-08 & 31.0 & 44.3 & 38.1 & 37.1 & 33.2 & 56.1 & 24.1 & 58.6 \\
\hline Nov-08 & 49.8 & 62.7 & 47.4 & 41.3 & 51.7 & 62.0 & 38.9 & 63.3 \\
\hline Dec-08 & 57.2 & 70.2 & 54.6 & 45.6 & 59.5 & 68.0 & 55.9 & 72.5 \\
\hline Jan-09 & 58.8 & 67.3 & 53.1 & 46.3 & 55.4 & 66.5 & 62.2 & 58.6 \\
\hline Feb-09 & 59.9 & 76.0 & 61.4 & 51.4 & 58.1 & 67.7 & 71.6 & 74.3 \\
\hline Mar-09 & 63.8 & 71.8 & 65.0 & 45.5 & 53.9 & 74.0 & 79.8 & 72.6 \\
\hline Apr-09 & 65.4 & 70.2 & 58.3 & 31.8 & 50.7 & 68.6 & 78.9 & 70.4 \\
\hline Мay-09 & 60.4 & 67.4 & 52.7 & 31.0 & 41.1 & 64.6 & 77.7 & 67.9 \\
\hline Jun-09 & 53.0 & 65.3 & 42.5 & 34.4 & 38.6 & 61.0 & 74.8 & 64.6 \\
\hline Pre08 avge & 23.7 & 26.2 & 39.0 & 8.0 & 3.9 & 29.4 & 32.1 & 38.7 \\
\hline
\end{tabular}




\begin{tabular}{|c|c|c|c|c|c|c|c|c|c|}
\hline & Ireland & Italy & Luxembourg & Malta & Netherlands & Portugal & Spain & Sweden & UK \\
\hline Jan-07 & 9.9 & 17.0 & 25.3 & 3.8 & -18.7 & 39.1 & 11.1 & -16.8 & 32.8 \\
\hline Feb-07 & 25.0 & 17.8 & 30.7 & 0.5 & -22.2 & 39.0 & 8.5 & -22.2 & 29.6 \\
\hline Mar-07 & 34.8 & 17.0 & 30.5 & 1.7 & -20.6 & 45.9 & 10.2 & -17.1 & 30.3 \\
\hline Apr-07 & 46.4 & 16.5 & 26.9 & 13.5 & -15.3 & 41.6 & 6.2 & -22.0 & 28.6 \\
\hline May-07 & 19.5 & 16.7 & 17.7 & 12.5 & -10.6 & 37.7 & 7.8 & -22.7 & 26.2 \\
\hline Jun-07 & 25.9 & 22.0 & 20.2 & 11.3 & -19.8 & 44.3 & 7.0 & -19.9 & 27.2 \\
\hline Jul-07 & 37.1 & 16.4 & 12.5 & 7.1 & -23.7 & 42.3 & 7.2 & -20.7 & 25.9 \\
\hline Aug-07 & 38.1 & 19.7 & 15.4 & 14.3 & -18.5 & 42.3 & 7.4 & -19.2 & 27.1 \\
\hline Sep-07 & 35.4 & 17.4 & 17.6 & 20.3 & -11.1 & 46.0 & 20.1 & -19.3 & 25.5 \\
\hline Oct-07 & 39.5 & 22.0 & 20.4 & 15.0 & -11.7 & 46.1 & 16.8 & -17.8 & 27.0 \\
\hline Nov-07 & 42.8 & 22.8 & 17.0 & 19.0 & -10.1 & 44.3 & 18.8 & -12.3 & 28.9 \\
\hline Dec-07 & 46.4 & 21.7 & 20.1 & -3.8 & -12.4 & 47.9 & 20.2 & -7.4 & 27.7 \\
\hline Jan-08 & 47.0 & 18.8 & 19.3 & -3.8 & -11.1 & 50.1 & 25.4 & -2.8 & 27.7 \\
\hline Feb-08 & 52.5 & 23.2 & 22.0 & -3.3 & -4.5 & 47.9 & 28.3 & 6.8 & 29.6 \\
\hline Mar-08 & 50.1 & 24.4 & 20.1 & -12.7 & -5.1 & 44.4 & 24.2 & 6.6 & 29.4 \\
\hline Apr-08 & 58.6 & 22.6 & 17.8 & -10.6 & -2.3 & 45.6 & 30.9 & 11.6 & 34.6 \\
\hline May-08 & 35.5 & 14.7 & 18.3 & 0.3 & -4.1 & 48.8 & 39.0 & 16.7 & 31.0 \\
\hline Jun-08 & 46.2 & 15.0 & 15.6 & 1.5 & -0.8 & 49.7 & 44.0 & 23.3 & 37.7 \\
\hline Jul-08 & 51.5 & 26.1 & 22.3 & 4.8 & -0.2 & 53.9 & 51.7 & 26.9 & 47.9 \\
\hline Aug-08 & 53.6 & 24.5 & 22.2 & 6.8 & 5.9 & 44.3 & 45.5 & 33.6 & 49.8 \\
\hline Sep-08 & 46.1 & 25.8 & 24.7 & 3.3 & 10.9 & 38.2 & 56.2 & 35.5 & 51.5 \\
\hline Oct-08 & 67.1 & 33.4 & 43.8 & 15.8 & 27.0 & 53.3 & 63.3 & 59.1 & 60.0 \\
\hline Nov-08 & 70.6 & 42.7 & 54.0 & 30.2 & 47.3 & 64.0 & 66.5 & 64.9 & 65.9 \\
\hline Dec-08 & 73.4 & 50.2 & 66.3 & 24.3 & 63.7 & 65.9 & 71.2 & 67.1 & 71.2 \\
\hline Jan-09 & 72.8 & 45.5 & 65.9 & 22.1 & 66.4 & 76.8 & 67.4 & 61.7 & 75.3 \\
\hline Feb-09 & 79.4 & 51.6 & 70.4 & 41.3 & 76.3 & 85.6 & 67.8 & 58.2 & 68.1 \\
\hline Mar-09 & 80.9 & 57.6 & 70.1 & 33.5 & 80.0 & 76.9 & 59.4 & 61.6 & 65.2 \\
\hline Apr-09 & 70.9 & 45.8 & 75.2 & 33.2 & 70.6 & 72.6 & 50.9 & 67.2 & 59.2 \\
\hline Мау-09 & 72.3 & 39.0 & 65.9 & 31.4 & 57.2 & 71.8 & 35.0 & 48.4 & 56.6 \\
\hline Jun-09 & 58.0 & 38.4 & 64.3 & 27.0 & 64.0 & 65.5 & 31.3 & 40.6 & 55.5 \\
\hline \multicolumn{2}{|c|}{ Pre08 avge 20.3} & 28.4 & 31.7 & 16.7 & 10.4 & 30.5 & 17.4 & 7.3 & 20.1 \\
\hline
\end{tabular}


Eastern Europe

\begin{tabular}{|c|c|c|c|c|c|c|c|c|c|c|c|c|}
\hline & Bulgaria & Croatia & Czechia & Estonia & Latvia & Lithuania & Hungary & Poland & Romania & Slovenia & Slovakia & Turkey \\
\hline Jan-07 & 11.9 & 11.0 & 6.1 & -19.1 & -5.1 & -31.7 & 55.8 & -9.5 & 10.5 & 11.2 & -19.5 & NA \\
\hline Feb-07 & 6.4 & 11.5 & 6.2 & -15.1 & 0.4 & -28.7 & 58.0 & -4.8 & 17.5 & 8.9 & -13.0 & NA \\
\hline Mar-07 & 7.2 & 9.7 & 2.2 & -14.6 & -0.5 & -28.4 & 52.8 & -7.8 & 15.8 & 13.4 & -9.5 & NA \\
\hline Apr-07 & 5.5 & 5.6 & 3.6 & -12.3 & -4.2 & -29.6 & 51.1 & -15.3 & 18.5 & 12.9 & -16.5 & NA \\
\hline May-07 & 3.3 & 10.1 & 2.6 & -7.1 & -1.7 & -31.0 & 53.0 & -17.9 & 17.4 & 12.3 & -13.9 & 20.9 \\
\hline Jun-07 & 4.6 & 9.3 & 1.0 & -10.9 & -6.8 & -33.1 & 53.4 & -17.1 & 17.7 & 11.0 & -17.9 & 21.3 \\
\hline Jul-07 & 9.8 & 8.3 & 2.5 & -8.8 & -8.8 & -30.8 & 50.6 & -20.2 & 13.2 & 5.5 & -15.5 & 19.1 \\
\hline Aug-07 & 10.9 & 9.6 & 0.4 & -4.1 & -5.5 & -27.5 & 50.8 & -16.8 & 17.1 & 7.2 & -13.4 & 11.7 \\
\hline Sep-07 & 11.0 & 14.4 & -2.2 & -1.2 & -8.5 & -22.6 & 52.7 & -16.2 & 13.6 & 10.1 & -6.3 & 12.4 \\
\hline Oct-07 & 13.6 & 12.1 & -1.5 & -2.9 & -2.5 & -23.7 & 52.3 & -15.0 & 16.0 & 11.9 & -6.0 & 19.3 \\
\hline Nov-07 & 11.4 & 6.9 & 4.5 & 3.8 & -3.0 & -18.7 & 54.0 & -11.9 & 19.7 & 13.4 & -5.1 & 23.4 \\
\hline Dec-07 & 13.0 & 12.8 & 5.2 & 10.6 & -3.4 & -16.9 & 49.4 & -14.9 & 15.2 & 10.0 & -12.5 & 20.8 \\
\hline Jan-08 & 7.1 & 9.1 & 2.1 & 9.9 & 4.2 & -23.0 & 47.3 & -12.2 & 17.5 & 8.3 & -14.0 & 20.6 \\
\hline Feb-08 & 11.3 & 10.0 & -1.9 & 17.8 & 7.9 & -21.2 & 45.6 & -16.8 & 20.0 & 11.0 & -8.9 & 32.0 \\
\hline Mar-08 & 7.4 & 14.9 & -1.8 & 19.5 & 11.0 & -17.5 & 48.5 & -13.5 & 14.1 & 14.6 & -5.9 & 36.0 \\
\hline Apr-08 & 10.1 & 6.4 & 1.5 & 22.9 & 22.0 & -14.4 & 48.3 & -16.9 & 13.1 & 4.6 & -10.0 & 37.9 \\
\hline May-08 & 3.7 & 12.1 & 0.9 & 34.0 & 22.0 & -3.3 & 46.5 & -16.5 & 11.3 & 12.4 & -7.6 & 39.6 \\
\hline Jun-08 & 10.0 & 17.6 & 0.8 & 27.9 & 25.5 & 4.4 & 46.1 & -11.0 & 13.7 & 7.0 & -14.8 & 39.2 \\
\hline Jul-08 & 9.3 & 13.5 & 4.6 & 31.6 & 28.2 & 12.3 & 44.4 & -9.6 & 13.0 & 12.8 & -10.3 & 35.6 \\
\hline Aug-08 & 6.1 & 15.6 & 13.7 & 34.9 & 34.9 & 23.5 & 42.3 & -7.8 & 12.1 & 15.3 & -8.6 & 30.2 \\
\hline Sep-08 & 2.8 & 15.1 & 11.3 & 37.7 & 40.1 & 24.1 & 43.9 & -6.0 & 15.0 & 10.9 & -6.3 & 36.0 \\
\hline Oct-08 & 13.5 & 20.0 & 36.6 & 49.6 & 51.2 & 39.7 & 64.2 & 2.3 & 14.2 & 16.9 & -0.1 & 42.7 \\
\hline Nov-08 & 39.4 & 28.0 & 45.3 & 56.0 & 61.9 & 53.2 & 73.1 & 12.9 & 48.0 & 52.7 & 48.8 & 52.2 \\
\hline Dec-08 & 55.7 & 43.4 & 57.7 & 61.4 & 74.8 & 71.1 & 81.4 & 24.2 & 59.5 & 60.9 & 51.8 & 50.5 \\
\hline Jan-09 & 51.8 & 49.1 & 65.0 & 58.2 & 78.6 & 77.7 & 82.3 & 33.9 & 66.5 & 72.7 & 53.7 & 45.5 \\
\hline Feb-09 & 55.7 & 56.6 & 64.9 & 67.4 & 80.1 & 82.1 & 84.0 & 57.3 & 70.0 & 65.2 & 76.3 & 41.1 \\
\hline Mar-09 & 58.2 & 59.6 & 49.1 & 65.8 & 74.8 & 81.8 & 80.1 & 59.2 & 73.5 & 67 & 76.5 & 37.2 \\
\hline Apr-09 & 62.9 & 54.3 & 48.8 & 59.1 & 58.4 & 77.1 & 81.1 & 44.5 & 70.9 & 71.4 & 63.0 & 28.4 \\
\hline May-09 & 56.4 & 47.8 & 43.0 & 50.3 & 48.8 & 75.4 & 74.9 & 40.4 & 70.6 & 56.3 & 54.7 & 28.5 \\
\hline Jun-09 & 54.7 & 55.5 & 38.7 & 44.8 & 57.6 & 67.4 & 69.9 & 29.1 & 63.6 & 46.1 & 50.7 & 24.0 \\
\hline pre '08 avge & e 16.9 & 17.4 & 27.8 & 27.2 & 22.1 & -2.5 & 30.3 & 23.2 & 33.6 & 24.4 & 17.3 & 18.6 \\
\hline
\end{tabular}




\section{Chart 1 GDP projection based on market interest rate expectations}

Percentage increases in output on a year earlier

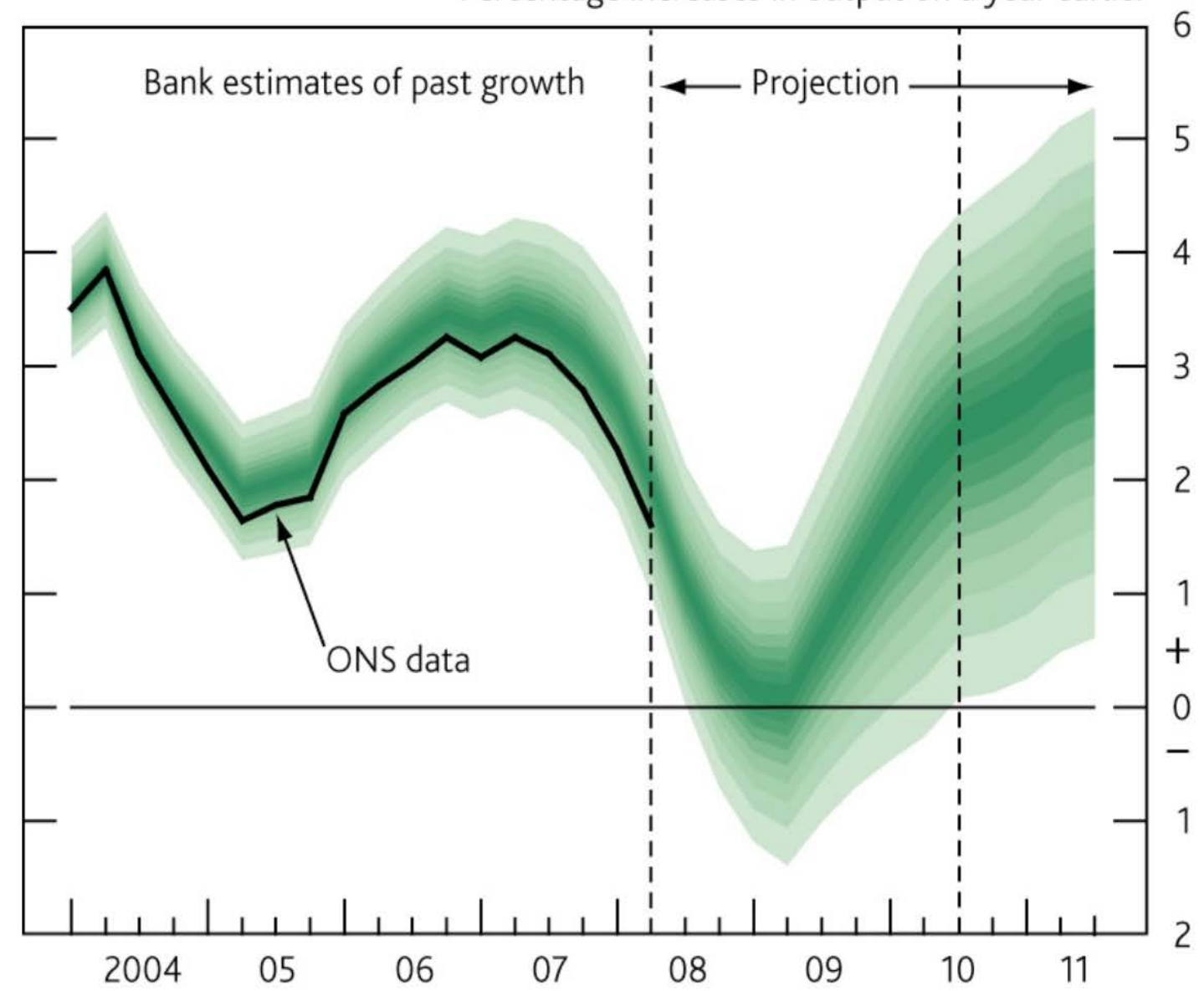

The fan chart depicts the probability of various outcomes for GDP growth. To the left of the first vertical dashed line, the distribution reflects the likelihood of revisions to the data over the past; to the right, it reflects uncertainty over the evolution of GDP growth in the future. If economic circumstances identical to today's were to prevail on 100 occasions, the MPC's best collective judgement is that the mature estimate of GDP would lie within the darkest central band on only 10 of those occasions. The fan chart is constructed so that outturns are also expected to lie within each pair of the lighter green areas on 10 occasions. Consequently, GDP growth is expected to lie somewhere within the entire fan on 90 out of 100 occasions. The bands widen as the time horizon is extended, in dicating the increasing uncertainty about outcomes. See the box on page 39 of the November 2007 Inflation Report for a fuller description of the fan chart and what it represents. The second dashed line is drawn at the two-year point of the projection. 
Chart 2. US Unemployment rate and Sahm rule, 1971-2021

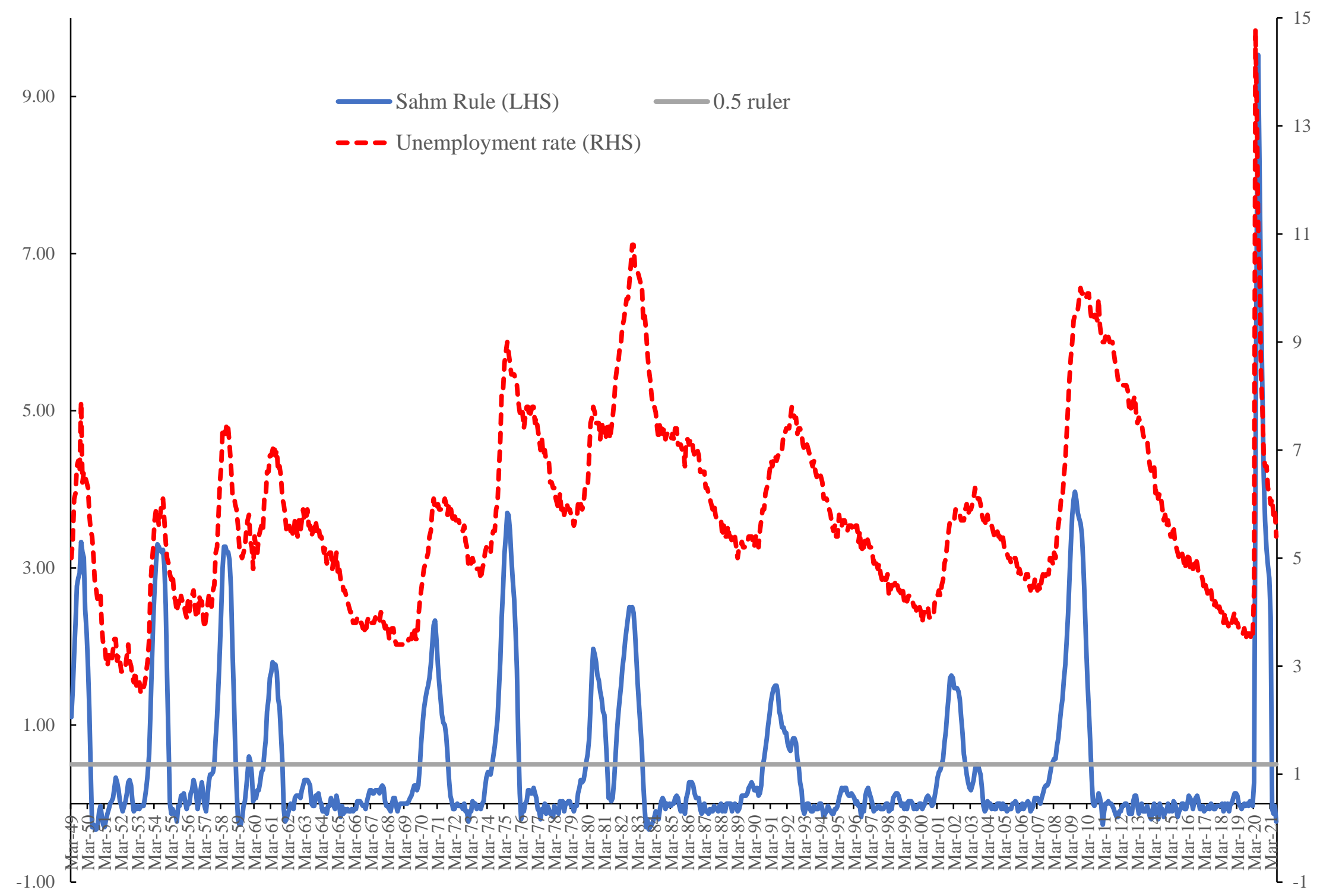




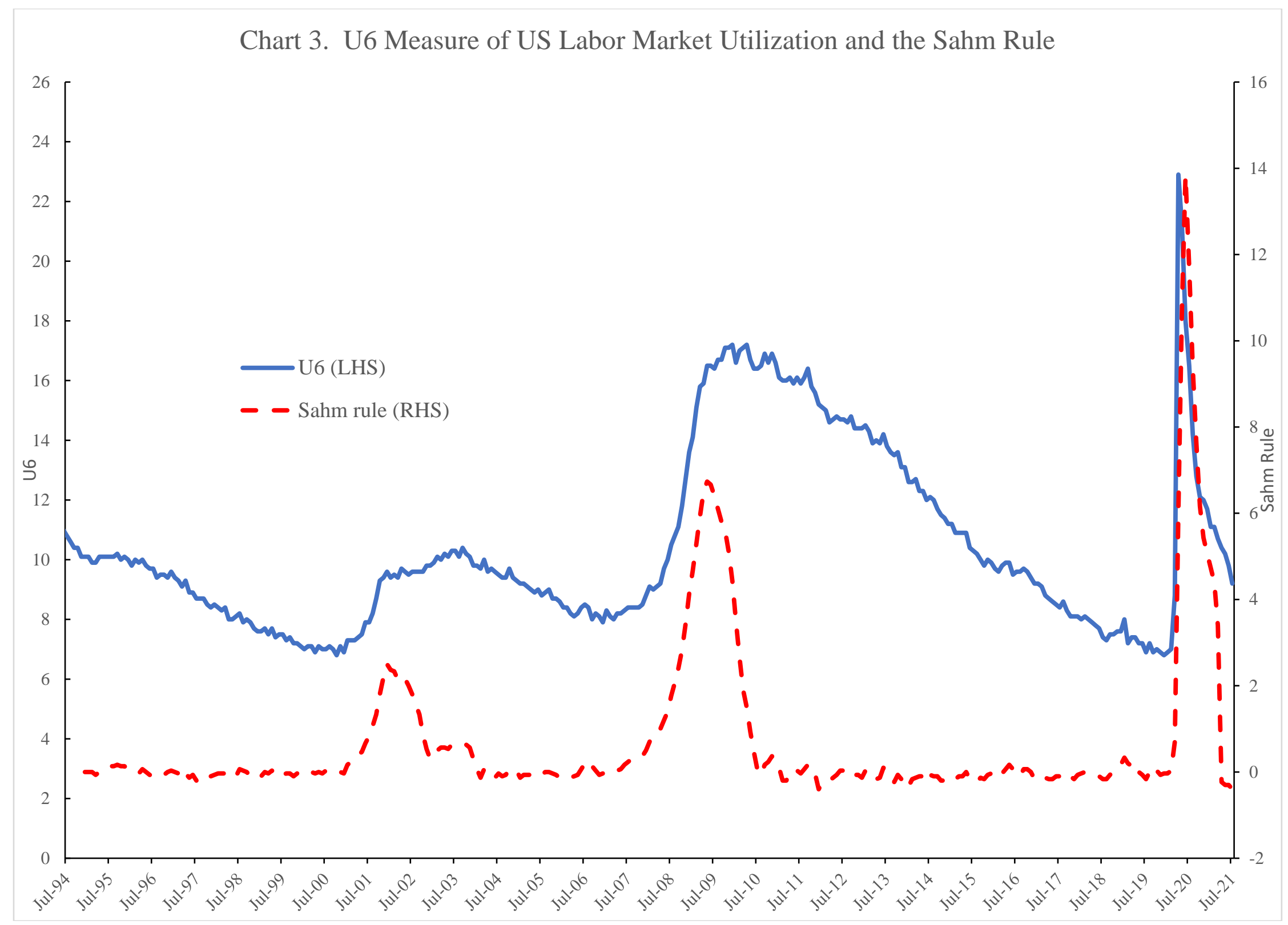




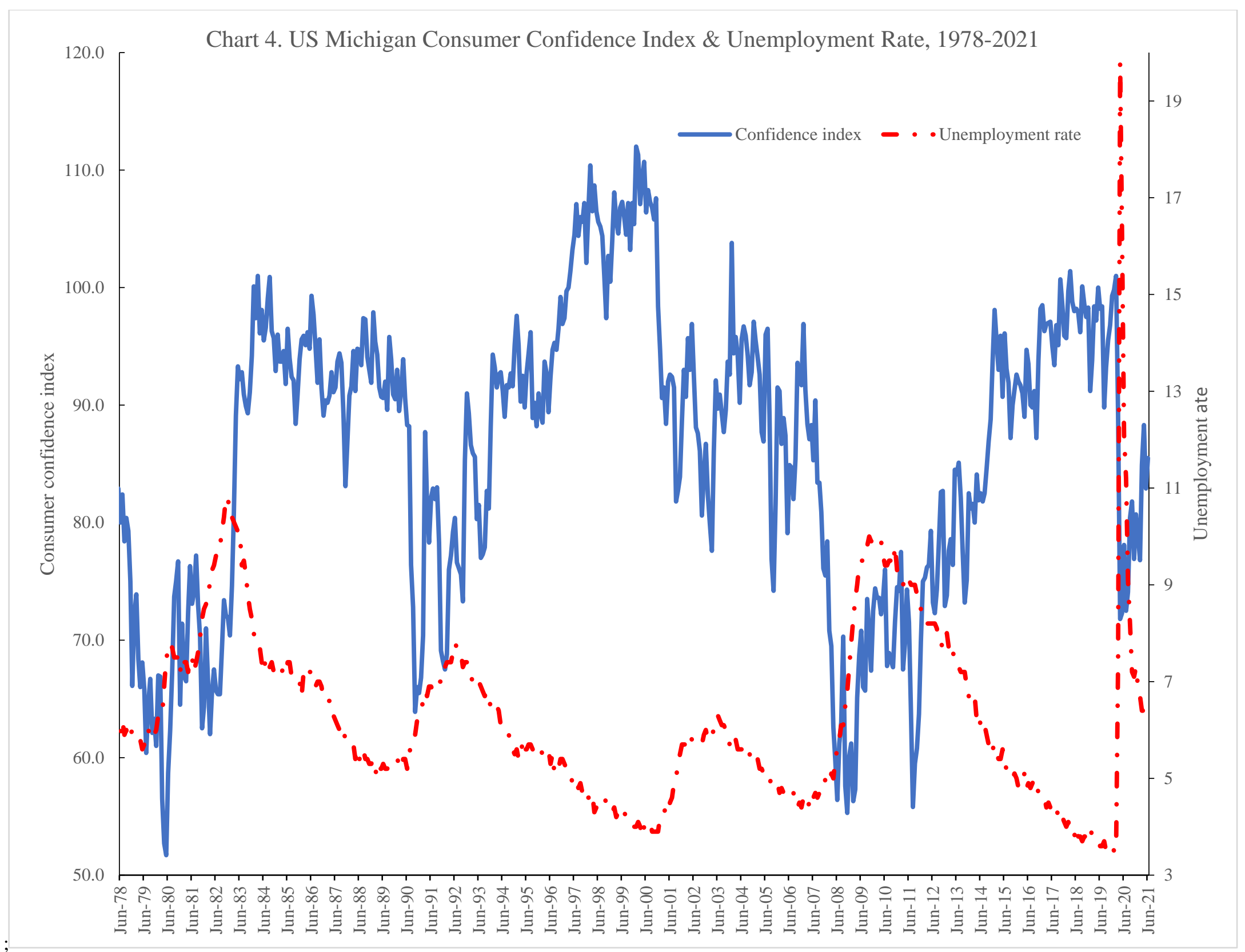




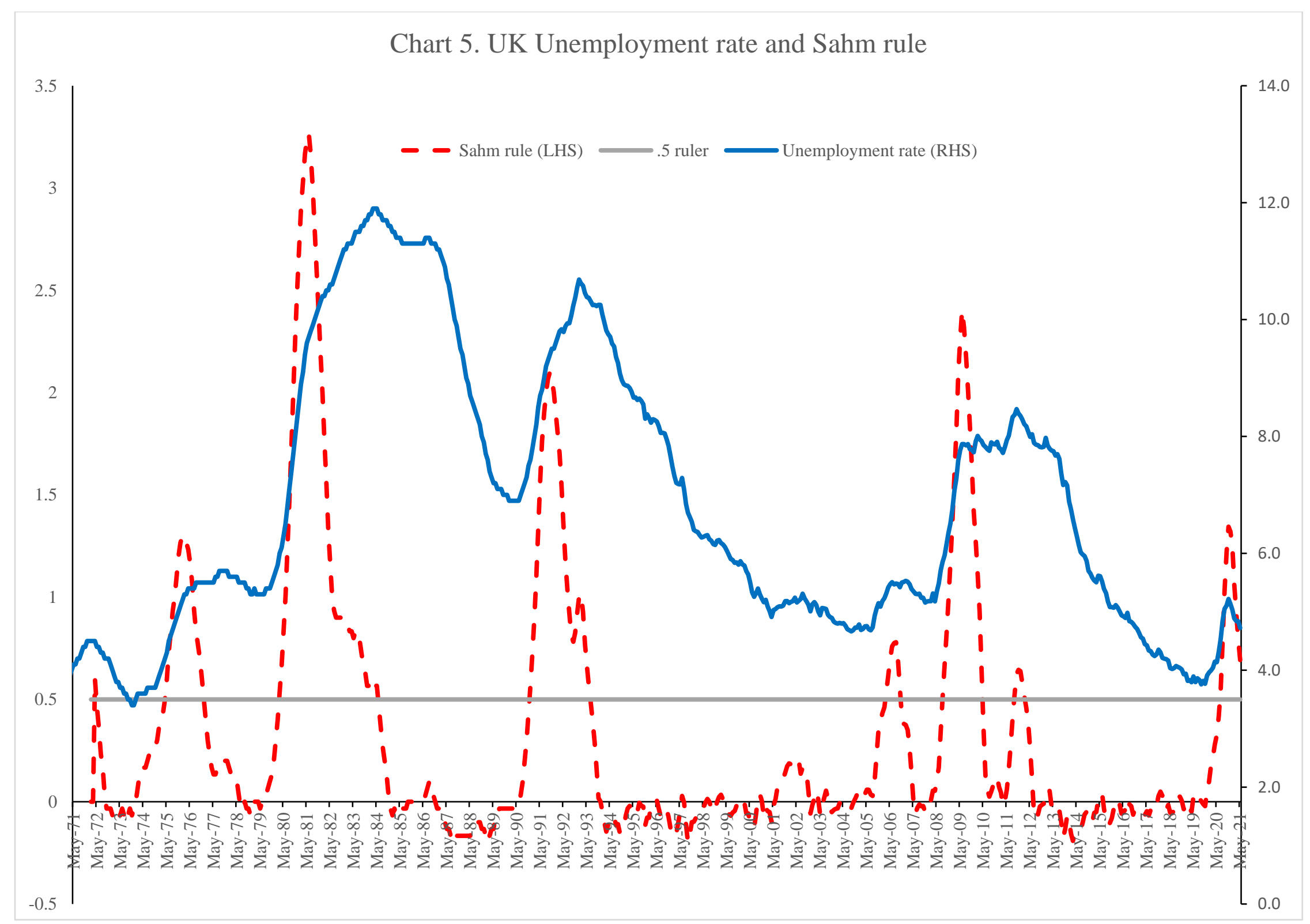




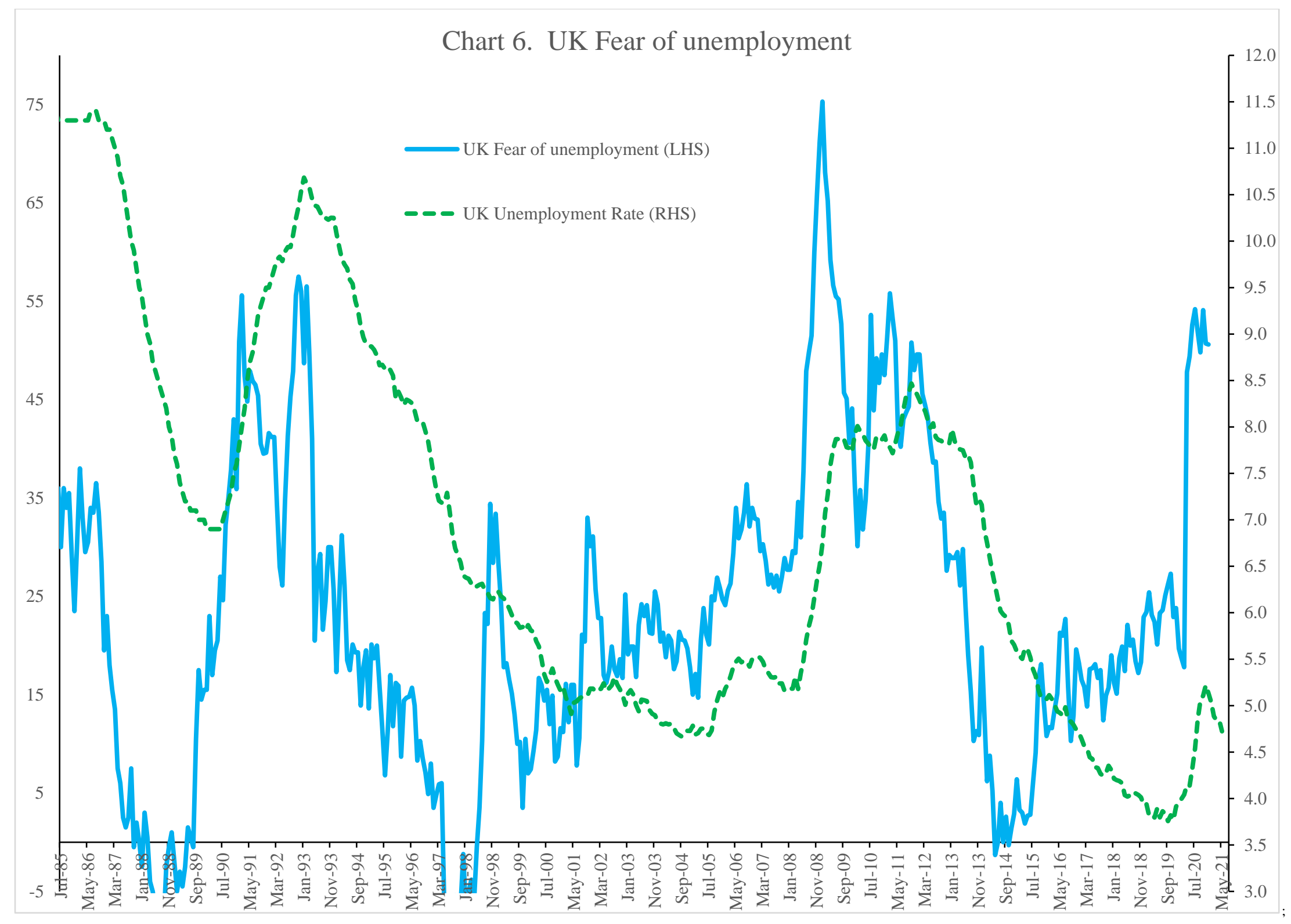




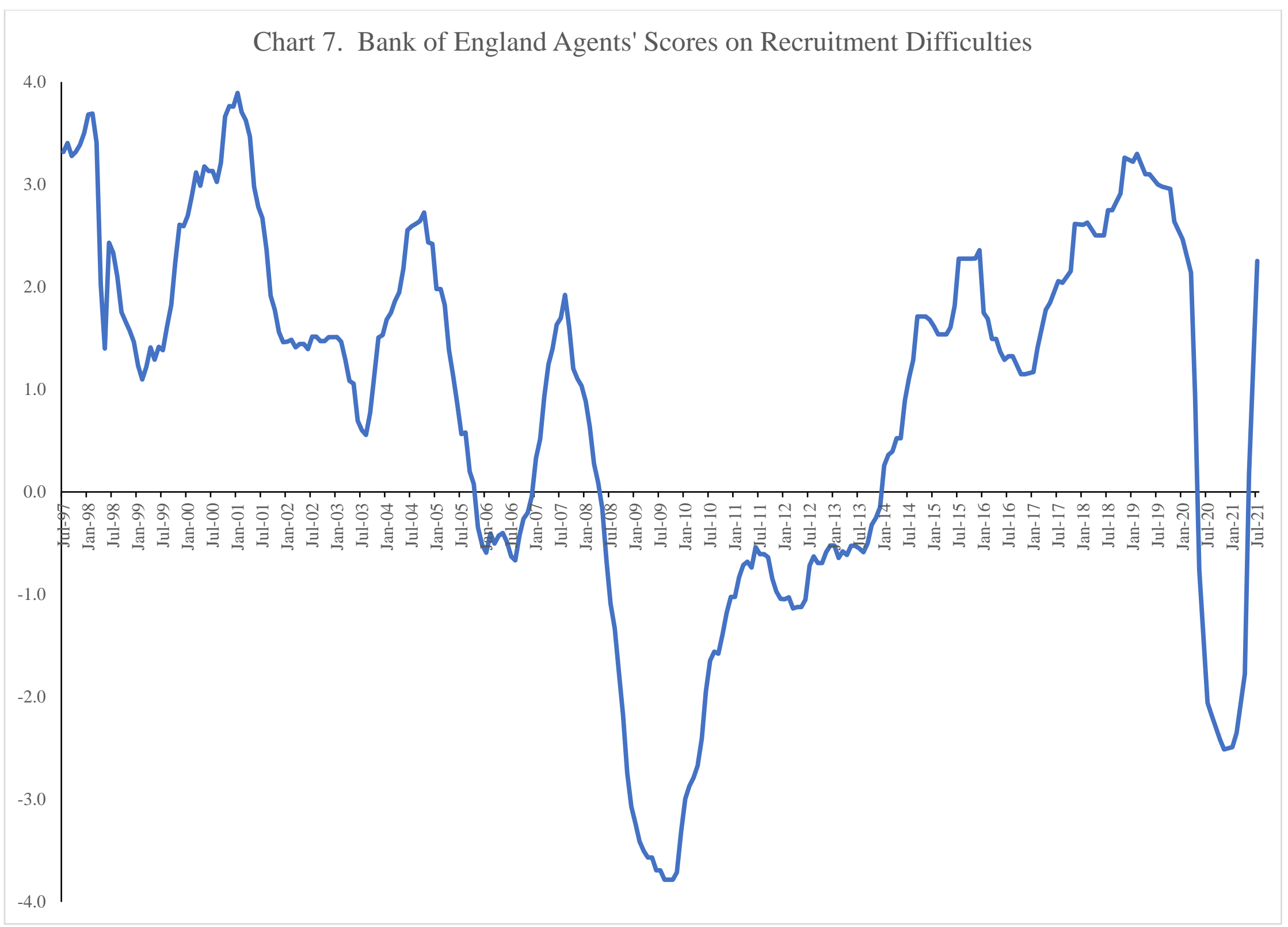




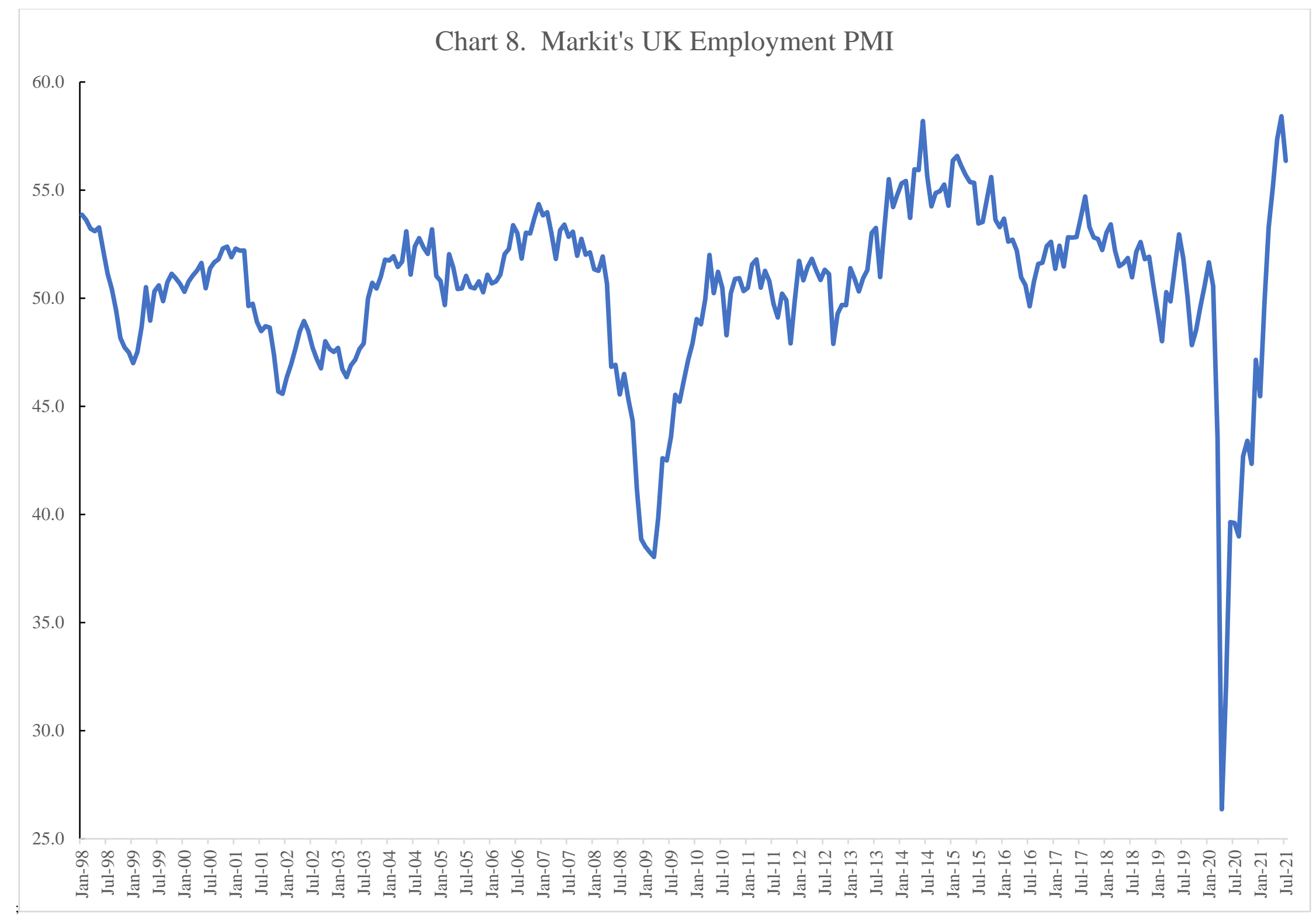


Chart 9. MPC’s Indicator of household's employment expectations, August 2008.

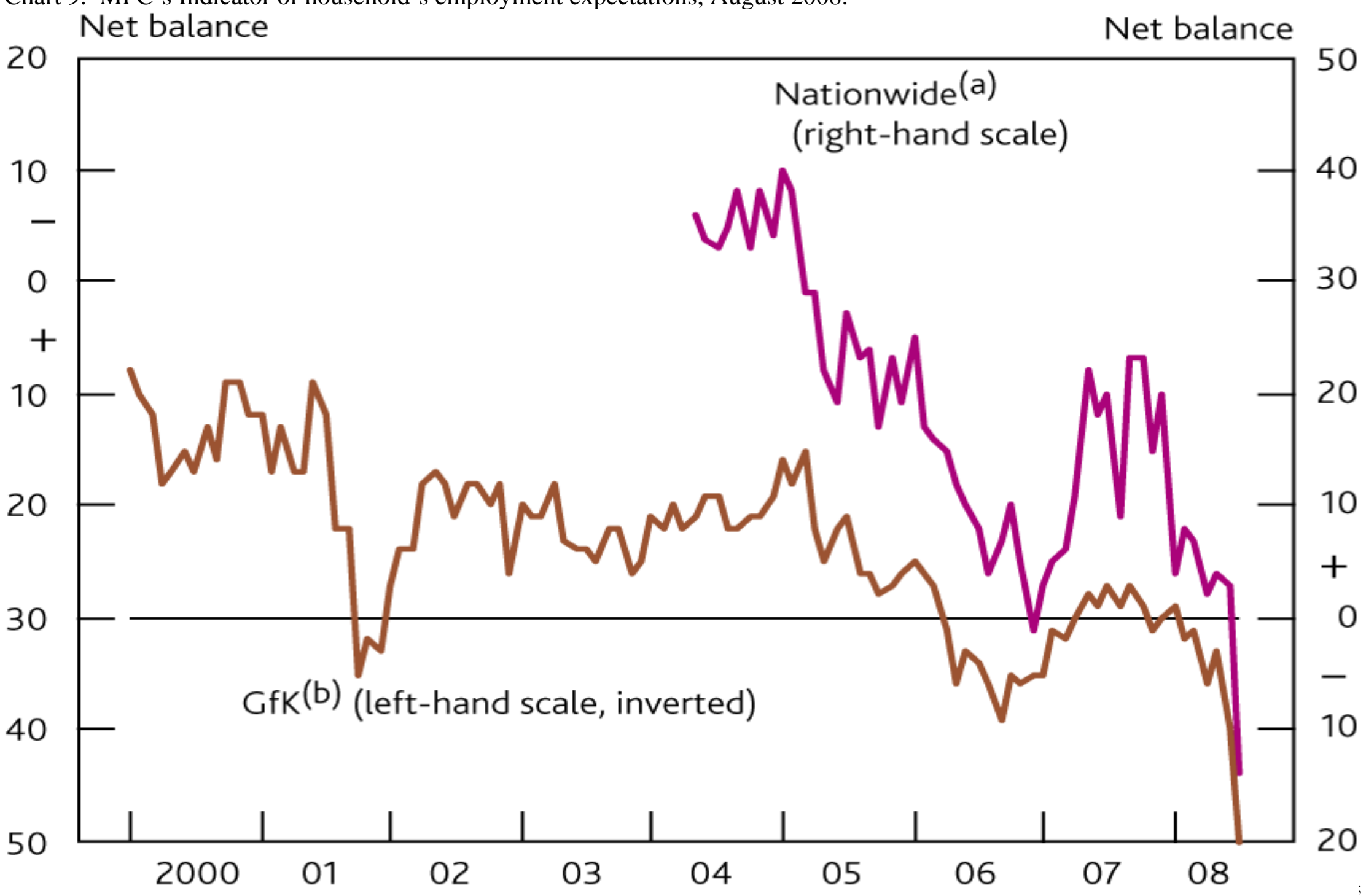

Sources: Nationwide and research carried out by GfK NOP on behalf of the European Commission.; (a) The Nationwide survey asks respondents whether they think there will be many or few jobs available in six months' time.; (b) Non seasonally adjusted. The GfK survey asks respondents how they expect unemployment to evolve over the next year. The series has been inverted, such that a lower net balance reflects an increase in unemployment expectatio 
Appendix Table 1. Monthly Unemployment rates December 2007-April 2009 OECD and EU Countries. Green shows Sahm Rule month>0.5.

\begin{tabular}{|c|c|c|c|c|c|c|c|c|c|c|c|c|c|c|c|c|c|}
\hline & Dec & Jan & Feb & Mar & Apr & May & Jun & Jul & Aug & Sep & Oct & Nov & Dec & Jan & Feb & Mar & Apr \\
\hline & 2007 & 2008 & 2008 & 2008 & 2008 & 2008 & 2008 & 2008 & 2008 & 2008 & 2008 & 2008 & 2008 & 2009 & 2009 & 2009 & 2009 \\
\hline Australia & 4.3 & 4.2 & 4.0 & 4.1 & 4.3 & 4.3 & 4.2 & 4.3 & 4.0 & 4.3 & 4.3 & 4.5 & 4.6 & 4.9 & 5.3 & 5.7 & 5.5 \\
\hline Austria & 4.5 & 4.7 & 4.6 & 4.3 & 4.3 & 4.1 & 3.9 & 4.4 & 4.4 & 4.3 & 4.4 & 4.8 & 5.1 & 5.0 & 4.9 & 5.3 & 5.7 \\
\hline Belgium & 7.1 & 7.1 & 6.9 & 6.7 & 6.5 & 6.5 & 6.9 & 7.5 & 7.6 & 7.4 & 6.9 & 6.7 & 6.9 & 7.5 & 7.8 & 8.0 & 7.9 \\
\hline Bulgaria & 6.1 & 6.1 & 6.1 & 5.9 & 5.9 & 5.9 & 5.7 & 5.6 & 5.5 & 5.3 & 5.1 & 5.0 & 5.3 & 5.6 & 5.9 & 6.2 & 6.2 \\
\hline Canada & 6.1 & 5.9 & 6 & 6.2 & 6.1 & 6.1 & 6.1 & 6.1 & 6.1 & 6.1 & 6.2 & 6.6 & 6.9 & 7.4 & 8.0 & 8.2 & 8.3 \\
\hline Croatia & 9.3 & 9.2 & 9.0 & 8.9 & 8.7 & 8.6 & 8.6 & 8.4 & 8.4 & 8.4 & 8.3 & 8.3 & 8.4 & 8.5 & 8.7 & 8.9 & 9.1 \\
\hline Czechia & 4.8 & 4.8 & 4.5 & 4.3 & 4.4 & 4.1 & 4.6 & 4.3 & 4.1 & 4.4 & 4.1 & 4.4 & 4.8 & 5.2 & 5.6 & 5.9 & 6.3 \\
\hline Denmark & 3.3 & 3.2 & 3.2 & 3.3 & 3.3 & 3.5 & 3.7 & 3.8 & 3.9 & 3.8 & 3.9 & 4.2 & 4.7 & 4.9 & 5.1 & 5.5 & 5.9 \\
\hline Estonia & 4.1 & 4.3 & 4.4 & 4.3 & 4.5 & 3.9 & 4.2 & 5.2 & 6.3 & 6.8 & 6.9 & 7.6 & 9.3 & 10.3 & 11.0 & 11.9 & 12.5 \\
\hline Finland & 6.6 & 6.5 & 6.1 & 6.4 & 5.7 & 6.4 & 6.4 & 6.1 & 6.4 & 6.7 & 6.3 & 6.7 & 6.7 & 7.0 & 7.4 & 7.7 & 8.3 \\
\hline France & 7.5 & 7.4 & 7.2 & 7.2 & 7.3 & 7.3 & 7.4 & 7.4 & 7.5 & 7.5 & 7.6 & 7.8 & 8.1 & 8.3 & 8.6 & 8.8 & 9.0 \\
\hline Germany & 8.1 & 7.9 & 7.8 & 7.7 & 7.6 & 7.5 & 7.4 & 7.3 & 7.1 & 7.0 & 7.0 & 7.1 & 7.2 & 7.3 & 7.5 & 7.6 & 7.7 \\
\hline Greece & 8.4 & 7.7 & 7.7 & 8.4 & 7.8 & 7.2 & 7.8 & 7.5 & 7.5 & 8.0 & 7.6 & 7.8 & 8.6 & 9.0 & 9.1 & 9.0 & 9.4 \\
\hline Hungary & 8.1 & 8.0 & 7.9 & 7.7 & 7.8 & 7.7 & 7.5 & 7.5 & 7.7 & 7.6 & 7.8 & 8.1 & 8.4 & 8.7 & 9.3 & 9.9 & 9.4 \\
\hline Iceland & 2.7 & 2.8 & 2.8 & 2.8 & 2.9 & 3.0 & 3.2 & 3.5 & 3.8 & 4.0 & 4.4 & 4.9 & 5.4 & 6.1 & 6.7 & 7.1 & 7.4 \\
\hline Ireland & 5.3 & 5.3 & 5.3 & 5.5 & 5.6 & 5.9 & 6.3 & 6.9 & 7.4 & 7.8 & 8.1 & 8.5 & 9.0 & 10.1 & 10.9 & 11.6 & 12.2 \\
\hline Italy & 6.6 & 6.6 & 6.7 & 6.4 & 6.9 & 6.8 & 6.9 & 6.6 & 6.8 & 6.8 & 7.0 & 7.1 & 6.8 & 7.2 & 7.3 & 7.7 & 7.5 \\
\hline Japan & 3.7 & 3.9 & 4.0 & 3.8 & 3.9 & 4.0 & 4.0 & 3.9 & 4.1 & 4.0 & 3.8 & 4.0 & 4.4 & 4.3 & 4.6 & 4.8 & 5.0 \\
\hline Korea & 3.2 & 3.0 & 3.0 & 3.0 & 3.1 & 3.2 & 3.1 & 3.1 & 3.3 & 3.2 & 3.3 & 3.4 & 3.4 & 3.3 & 3.3 & 3.5 & 3.6 \\
\hline Latvia & 5.6 & 6.2 & 6.5 & 6.4 & 6.3 & 6.4 & 6.6 & 7.0 & 7.6 & 8.4 & 9.6 & 10.6 & 11.3 & 12.4 & 13.7 & 14.9 & 16.0 \\
\hline Lithuania & 4.1 & 4.2 & 4.2 & 4.1 & 4.1 & 4.3 & 4.8 & 5.6 & 6.4 & 7.1 & 7.7 & 8.3 & 9.0 & 9.8 & 10.7 & 11.6 & 12.6 \\
\hline Luxembourg & 4.2 & 4.3 & 4.5 & 4.4 & 4.7 & 4.8 & 4.9 & 4.9 & 5.0 & 5.1 & 5.2 & 5.2 & 5.3 & 5.4 & 5.4 & 5.4 & 5.3 \\
\hline Mexico & 3.8 & 3.8 & 3.8 & 4.0 & 3.7 & 3.6 & 3.7 & 3.8 & 3.9 & 4.0 & 4.0 & 4.7 & 4.8 & 4.8 & 5.2 & 5.1 & 5.4 \\
\hline Netherlands & 3.9 & 3.8 & 3.6 & 3.6 & 3.7 & 3.7 & 3.7 & 3.6 & 3.6 & 3.6 & 3.6 & 3.6 & 3.7 & 3.7 & 3.8 & 3.9 & 4.1 \\
\hline Norway & 2.5 & 2.5 & 2.5 & 2.4 & 2.4 & 2.6 & 2.7 & 2.8 & 2.8 & 2.9 & 3.0 & 3.1 & 3.1 & 3.1 & 3.0 & 3.1 & 3.2 \\
\hline Poland & 8.3 & 7.8 & 7.5 & 7.3 & 7.2 & 7.2 & 7.0 & 6.9 & 6.8 & 6.7 & 6.6 & 6.8 & 7.0 & 7.4 & 7.7 & 7.9 & 7.9 \\
\hline Portugal & 9.2 & 9.0 & 8.9 & 9.0 & 9.0 & 9.1 & 9.3 & 9.2 & 9.4 & 9.4 & 9.4 & 9.4 & 9.7 & 10.0 & 10.2 & 10.5 & 10.8 \\
\hline Romania & 6.0 & 5.6 & 5.5 & 5.6 & 5.5 & 5.7 & 5.7 & 5.5 & 5.5 & 5.5 & 5.7 & 5.5 & 5.8 & 5.8 & 6.1 & 6.0 & 6.0 \\
\hline Slovakia & 110.5 & 10.4 & 10.3 & 10.2 & 10.2 & 10.2 & 9.9 & 9.4 & 9.0 & 8.8 & 8.7 & 8.9 & 9.1 & 9.6 & 10.2 & 10.7 & 11.0 \\
\hline Slovenia & 4.7 & 4.8 & 4.7 & 4.6 & 4.4 & 4.4 & 4.3 & 4.3 & 4.3 & 4.2 & 4.2 & 4.3 & 4.3 & 4.6 & 4.9 & 5.2 & 5.5 \\
\hline Spain & 8.8 & 9.1 & 9.3 & 9.5 & 10.0 & 10.4 & 10.8 & 11.1 & 11.5 & 12.0 & 12.9 & 13.8 & 14.8 & 15.9 & 16.8 & 17.5 & 17.8 \\
\hline Sweden & 6.0 & 6.0 & 5.8 & 5.8 & 5.6 & 5.8 & 6.6 & 6.2 & 5.9 & 6.4 & 6.3 & 7.0 & 6.8 & 6.8 & 7.7 & 7.8 & 7.8 \\
\hline Turkey & 9.3 & 9.3 & 9.5 & 9.4 & 9.2 & 9.2 & 9.6 & 9.9 & 9.8 & 10.2 & 10.6 & 11.5 & 1.02 & 12.6 & 13.0 & 13.7 & 14.0 \\
\hline UK & 5.2 & 5.2 & 5.2 & 5.3 & 5.2 & 5.4 & 5.5 & 5.7 & 5.9 & 6.0 & 6.2 & 6.4 & 6.5 & 6.7 & 7.1 & 7.3 & 7.6 \\
\hline \multirow[t]{2}{*}{ USA } & 5.0 & 5.0 & 4.9 & 5.1 & 5.0 & 5.4 & 5.6 & 5.8 & 6.1 & 6.1 & 6.5 & 6.8 & 7.3 & 7.8 & 8.3 & 8.7 & 9.0 \\
\hline & Netherlands & Korea & & & & & & & & & & & & & & & \\
\hline Feb-09 & 3.8 & 3.3 & & & & & & & & & & & & & & & \\
\hline Mar-09 & 3.9 & 3.5 & & & & & & & & & & & & & & & \\
\hline Apr-09 & 4.1 & 3.6 & & & & & & & & & & & & & & & \\
\hline May-09 & 4.2 & 3.9 & & & & & & & & & & & & & & & \\
\hline \multirow[t]{2}{*}{ Jun-09 } & 4.3 & 3.9 & & & & & & & & & & & & & & & \\
\hline & Ireland & Spain & Hungary & & & & & & & & & & & & & & \\
\hline Sep-07 & 4.9 & 8.3 & 7.3 & & & & & & & & & & & & & & \\
\hline Oct-07 & 5.1 & 8.4 & 7.5 & & & & & & & & & & & & & & \\
\hline Nov-07 & 5.2 & 8.6 & 7.8 & & & & & & & & & & & & & & \\
\hline Dec-07 & 5.3 & 8.8 & 8.1 & & & & & & & & & & & & & & \\
\hline
\end{tabular}


Appendix Table 2. Employment change 2007, for states with $>1$ negative month

\begin{tabular}{|c|c|c|c|c|c|c|c|c|c|c|c|c|c|}
\hline & Alabama & Alaska & Arkansas D & Delaware & $\mathrm{DC}$ & Florida & Hawaii & Idaho & Illinois & Indiana & Iowa & Kansas & Kentucky \\
\hline Jan-07 & -550 & 64 & 821 & 68 & 867 & 10,350 & -506 & 1,374 & $-2,701$ & -3328 & -1120 & 278 & 962 \\
\hline Feb-07 & $-2,179$ & -103 & -19 & -225 & 500 & 4,699 & -933 & 1,217 & $-3,918$ & -5827 & -1821 & -188 & -793 \\
\hline Mar-07 & $-3,216$ & -225 & -863 & -390 & 171 & -437 & -1298 & 1,077 & $-2,387$ & -7293 & -1740 & -474 & -2232 \\
\hline Apr-07 & $-3,411$ & -277 & -1307 & -321 & -17 & $-4,697$ & -1519 & 967 & 962 & -7411 & -1187 & -525 & -3135 \\
\hline Мay-07 & $-2,934$ & -175 & -1377 & -95 & -82 & $-8,055$ & -1502 & 833 & 4,592 & -6617 & -567 & -324 & -3456 \\
\hline Jun-07 & $-2,001$ & 22 & -1106 & 128 & -19 & $-9,427$ & -1297 & 596 & 7,247 & -4958 & 176 & 87 & -3081 \\
\hline Jul-07 & $-1,026$ & 256 & -521 & 298 & 352 & $-9,031$ & -1048 & 210 & 8,155 & -2484 & 742 & 484 & -2462 \\
\hline Aug-07 & -223 & 457 & 308 & 403 & 780 & $-6,995$ & -616 & -182 & 7,339 & 453 & 1147 & 741 & -1749 \\
\hline Sep-07 & 318 & 557 & 1281 & 475 & 1,082 & $-3,601$ & -1 & -484 & 6,391 & 3816 & 1706 & 878 & -629 \\
\hline Oct-07 & 66 & 561 & 1938 & 522 & 1,133 & $-1,803$ & 569 & -742 & 5,039 & 5880 & 2167 & 687 & 66 \\
\hline Nov-07 & -707 & 502 & 2192 & 634 & 988 & $-1,928$ & 1053 & -941 & 4,631 & 6363 & 2431 & 434 & 102 \\
\hline \multirow[t]{2}{*}{ Dec-07 } & $-1,673$ & 513 & 2212 & 714 & 721 & $-3,952$ & 1347 & $-1,064$ & 4,722 & 6181 & 2579 & 371 & -179 \\
\hline & Louisiana & Maine & Maryland & MA & MI & Minnesota & Mississippi & Missouri & Montana & NJ & NM & NY & $\mathrm{NC}$ \\
\hline Jan-07 & 1,926 & -198 & -395 & 1,900 & -5006 & -219 & -200 & 285 & 1638 & -538 & 1,082 & -736 & 4539 \\
\hline Feb-07 & 67 & -707 & -1815 & 1,196 & -7213 & $-1,759$ & -852 & -1085 & 1262 & $-2,805$ & 608 & $-5,295$ & 1773 \\
\hline Mar-07 & $-1,219$ & -1122 & -2310 & 584 & -8193 & $-2,897$ & -938 & -2147 & 680 & $-4,153$ & 233 & $-8,413$ & -378 \\
\hline Apr-07 & $-1,725$ & -1417 & -1728 & 160 & -8074 & $-3,337$ & -484 & -2539 & 164 & $-3,896$ & -15 & $-8,780$ & -791 \\
\hline May-07 & $-1,408$ & -1417 & -373 & -182 & -7713 & $-3,166$ & 247 & -2313 & -148 & $-2,311$ & -67 & $-6,711$ & -172 \\
\hline Jun-07 & -33 & -1086 & 1421 & -249 & -7293 & $-2,597$ & 1154 & -1721 & -196 & -226 & 123 & $-3,013$ & 410 \\
\hline Jul-07 & 2,238 & -575 & 2914 & -191 & -6766 & $-2,142$ & 2062 & -945 & -79 & 1,409 & 403 & 1,622 & 745 \\
\hline Aug-07 & 4,445 & -25 & 3837 & -33 & -5930 & $-1,832$ & 2811 & -72 & 136 & 2,410 & 763 & 5,894 & 1386 \\
\hline Sep-07 & 5,826 & 523 & 4688 & 648 & -4744 & $-1,341$ & 3244 & 736 & 420 & 3,451 & 1,170 & 10,112 & 2673 \\
\hline Oct-07 & 5,686 & 871 & 4936 & 1,480 & -4202 & -744 & 2993 & 647 & 665 & 4,242 & 1,378 & 11,392 & 3458 \\
\hline Nov-07 & 4,619 & 1018 & 4652 & 2,540 & -3759 & 41 & 2317 & 50 & 759 & 4,885 & 1,421 & 10,654 & 3977 \\
\hline \multirow[t]{2}{*}{ Dec-07 } & 3,523 & 1005 & 4307 & 3,182 & -4258 & 720 & 1455 & -544 & 738 & 4,831 & 1,376 & 8,888 & 4057 \\
\hline & Ohio & Oklahoma & a Oregon & PA & RI & SC & SD & Tennessee & Vermont & WV & Wisconsin & & \\
\hline Jan-07 & 2598 & 861 & 3,538 & 3,381 & 275 & 3,000 & 216 & 3352 & -448 & -507 & 344 & & \\
\hline Feb-07 & 366 & -30 & 1,906 & 315 & -63 & 569 & 54 & 455 & -535 & -860 & -481 & & \\
\hline Mar-07 & -636 & -909 & 220 & $-1,257$ & -445 & $-1,561$ & -49 & -1581 & -558 & -818 & -848 & & \\
\hline Apr-07 & -1465 & $-1,369$ & -902 & $-1,082$ & -783 & $-2,782$ & -70 & -2652 & -553 & -448 & -803 & & \\
\hline Маy-07 & -3061 & $-1,381$ & $-1,362$ & 88 & -976 & $-3,168$ & -22 & -2976 & -560 & 61 & -603 & & \\
\hline Jun-07 & -3989 & -767 & $-1,086$ & 1,886 & -958 & $-3,028$ & 49 & -2578 & -572 & 556 & -341 & & \\
\hline Jul-07 & -3833 & 81 & -88 & 3,527 & -793 & $-2,739$ & 113 & -2272 & -553 & 844 & 67 & & \\
\hline Aug-07 & -3336 & 961 & 1,449 & 4,829 & -630 & $-2,474$ & 185 & -2154 & -460 & 939 & 608 & & \\
\hline Sep-07 & -1356 & 2,006 & 2,934 & 6,113 & -587 & $-2,033$ & 306 & -1891 & -271 & 978 & 1397 & & \\
\hline Oct-07 & 442 & 2,700 & 3,718 & 6,215 & -757 & $-1,560$ & 364 & -2298 & -127 & 845 & 2158 & & \\
\hline Nov-07 & 1586 & 3,076 & 4,036 & 6,065 & -988 & $-1,075$ & 388 & -2619 & -27 & 618 & 3284 & & \\
\hline Dec-07 & 2237 & 3,468 & 4,027 & 6,733 & -1240 & -598 & 408 & -2131 & 46 & 525 & 4478 & & \\
\hline
\end{tabular}


Appendix Table 3. US quarterly GDP growth rates (\%)

\begin{tabular}{|c|c|c|c|c|c|c|c|c|}
\hline $2-1947^{1}$ & -0.3 & Q3-1958 & 2.3 & Q4-19695 & -0.5 & Q1-1981 & 2 & Q2-1992 \\
\hline Q3-1947 & -0.2 & Q4-1958 & 2.3 & Q1-1970 & -0.1 & Q2-1981 & -0.7 & Q3-1992 \\
\hline Q4-1947 & 1.6 & Q1-1959 & 1.9 & Q2-1970 & 0.1 & Q3-1981 & 1.2 & Q4-1992 \\
\hline Q1-1948 & 1.5 & Q2-1959 & 2.3 & Q3-1970 & 0.9 & Q4-1981 & -1.1 & Q1-1993 \\
\hline Q2-1948 & 1.7 & Q3-1959 & 0.1 & Q4-1970 & -1.1 & Q1-1982 & -1.6 & Q2-1993 \\
\hline Q3-1948 & 0.6 & Q4-1959 & 0.3 & Q1-1971 & 2.7 & Q2-1982 & 0.5 & Q3-1993 \\
\hline Q4-1948 & 0.1 & Q1-1960 & 2.2 & Q2-1971 & 0.5 & Q3-1982 & -0.4 & Q4-1993 \\
\hline Q1-1949² & -1.4 & Q2-1960 & -0.5 & Q3-1971 & 0.8 & Q4-1982 & 0 & Q1-1994 \\
\hline Q2-1949 & -0.3 & Q3-1960 & 0.5 & Q4-1971 & 0.2 & Q1-1983 & 1.3 & Q2-1994 \\
\hline Q3-1949 & 1.0 & Q4-1960 & -1.3 & Q1-1972 & 1.8 & Q2-1983 & 2.3 & Q3-1994 \\
\hline Q4-1949 & -0.8 & Q1-1961 & 0.7 & Q2-1972 & 2.3 & Q3-1983 & 2.0 & Q4-1994 \\
\hline Q1-1950 & 3.9 & Q2-1961 & 1.7 & Q3-1972 & 0.9 & Q4-1983 & 2.1 & Q1-1995 \\
\hline Q2-1950 & 3.0 & Q3-1961 & 1.9 & Q4-1972 & 1.7 & Q1-1984 & 2.0 & Q2-1995 \\
\hline Q3-1950 & 3.9 & Q4-1961 & 2.0 & Q1-1973 & 2.5 & Q2-1984 & 1.7 & Q3-1995 \\
\hline Q4-1950 & 1.9 & Q1-1962 & 1.8 & Q2-1973 & 1.1 & Q3-1984 & 1.0 & Q4-1995 \\
\hline Q1-1951 & 1.4 & Q2-1962 & 0.9 & Q3-1973 & -0.5 & Q4-1984 & 0.8 & Q1-1996 \\
\hline Q2-1951 & 1.7 & Q3-1962 & 1.2 & Q4-1973 & 0.9 & Q1-1985 & 1.0 & Q2-1996 \\
\hline Q3-1951 & 2.1 & Q4-1962 & 0.3 & Q1-1974 & -0.9 & 985 & 0.9 & Q3-1996 \\
\hline Q4-1951 & 0.2 & Q1-1963 & 1.1 & Q2-1974 & 0.2 & 85 & 1.5 & Q4-1996 \\
\hline Q1-1952 & 1.1 & Q2-1963 & 1.1 & Q3-19746 & -0.9 & Q4-1985 & 0.7 & Q1-1997 \\
\hline Q2-1952 & 0.2 & Q3-1963 & 2.2 & Q4-1974 & -0.4 & Q1-1986 & 0.9 & Q2-1997 \\
\hline Q3-1952 & 0.7 & Q4-1963 & 0.7 & Q1-1 & -1.2 & 886 & 0.5 & Q3-1997 \\
\hline Q4-1952 & 3.3 & Q1-1964 & 2.1 & Q2-1975 & 0.7 & Q3-1986 & 1.0 & Q4-1997 \\
\hline Q1-1953 & 1.9 & Q2-1964 & 1.1 & Q3-1975 & 1.7 & Q4-1986 & 0.5 & Q1-1998 \\
\hline Q2-1953 & 0.8 & Q3-1964 & 1.6 & Q4-1975 & 1.3 & Q1-1987 & 0.7 & Q2-1998 \\
\hline Q3-19533 & -0.6 & Q4-1964 & 0.3 & & 2.2 & & 1.1 & Q3-1998 \\
\hline Q4-1953 & -1.5 & Q1-1965 & 2.4 & Q2-1976 & 0.7 & Q3-1987 & 0.9 & Q4-1998 \\
\hline Q1-1954 & -0.5 & Q2-1965 & 1.3 & Q3-1 & 0.5 & 987 & 1.7 & Q1-1999 \\
\hline Q2-1954 & 0.1 & Q3-1965 & 2.2 & Q4-1976 & 0.7 & Q1-1988 & 0.5 & Q2-1999 \\
\hline Q3-1954 & 1.1 & Q4-1965 & 2.3 & & 1.2 & & 1.3 & Q3-1999 \\
\hline Q4-1954 & 2.0 & Q1-1 & 2.4 & & 1.9 & & 0.6 & Q4-1999 \\
\hline Q1-1955 & 2.9 & Q2-1966 & 0.3 & Q3-1977 & 1.8 & Q4-1988 & 1.3 & Q1-2000 \\
\hline Q2-1955 & 1.6 & Q3-1966 & 0.8 & Q4-1977 & 0 & Q1-1989 & 1.0 & Q2-2000 \\
\hline Q3-1955 & 1.4 & Q4-1966 & 0.8 & Q1-1978 & 0.3 & Q2-1989 & 0.8 & Q3-2000 \\
\hline Q4-1955 & 0.6 & Q1-19 & 0.9 & & 3.9 & & 0.7 & Q4-2000 \\
\hline Q1-1956 & -0.4 & & 0.1 & & 1.0 & & 0.2 & Q1-2 \\
\hline Q2-1956 & 0.8 & Q3-1967 & 0.9 & Q4-1978 & 1.3 & Q1-1 & 1.1 & Q2-2001 \\
\hline Q3-1956 & -0.1 & Q4-1967 & 0.8 & Q1-1979 & 0.2 & Q2-1990 & 0.4 & Q3-2001 \\
\hline Q4-1956 & 1.6 & Q1-1968 & 2.0 & Q2-1979 & 0.1 & Q3-1990 & 0.1 & Q4-2001 \\
\hline Q1-1957 & 0.6 & Q2-1968 & 1.7 & & 0.7 & Q4-1990 & -0.9 & Q1-2002 \\
\hline Q2-1957 & -0.2 & Q3-1968 & 0.8 & & 0.3 & Q1-1991 & -0.5 & Q2-2002 \\
\hline Q3-1957 & 1.0 & Q4-1968 & 0.4 & Q1-1980 & 0.3 & Q2-1991 & 0.8 & Q3-2002 \\
\hline Q4-19574 & -1.0 & Q1-1969 & 1.6 & Q2-19807 & -2.1 & Q3-1991 & 0.5 & Q4-2002 \\
\hline Q1-1958 & -2.6 & Q2-1969 & 0.3 & Q3-1980 & -0.1 & Q4-1991 & 0.3 & Q1-2003 \\
\hline Q2-1958 & 0.7 & Q3-1969 & 0.7 & Q4-1980 & 1.9 & Q1-1992 & 1.2 & Q2-2003 \\
\hline
\end{tabular}


Appendix Table 4. US quarterly GDP growth rates (\%) (continued)

\begin{tabular}{|c|c|c|c|}
\hline Q3-2003 & 1.7 & Q4-2013 & 0.7 \\
\hline Q4-2003 & 1.2 & Q1-2014 & -0.4 \\
\hline Q1-2004 & 0.6 & Q2-2014 & 1.3 \\
\hline Q2-2004 & 0.8 & Q3-2014 & 1.2 \\
\hline Q3-2004 & 0.9 & Q4-2014 & 0.4 \\
\hline Q4-2004 & 1.0 & Q1-2015 & 0.8 \\
\hline Q1-2005 & 1.1 & Q2-2015 & 0.6 \\
\hline Q2-2005 & 0.5 & Q3-2015 & 0.3 \\
\hline Q3-2005 & 0.8 & Q4-2015 & 0.1 \\
\hline Q4-2005 & 0.6 & Q1-2016 & 0.6 \\
\hline Q1-2006 & 1.3 & Q2-2016 & 0.3 \\
\hline Q2-2006 & 0.2 & Q3-2016 & 0.6 \\
\hline Q3-2006 & 0.2 & Q4-2016 & 0.5 \\
\hline Q4-2006 & 0.8 & Q1-2017 & 0.5 \\
\hline Q1-2007 & 0.3 & Q2-2017 & 0.6 \\
\hline Q2-2007 & 0.6 & Q3-2017 & 0.7 \\
\hline Q3-2007 & 0.6 & Q4-2017 & 0.9 \\
\hline Q4-2007 & 0.6 & Q1-2018 & 0.8 \\
\hline Q1-2008 & -0.4 & Q2-2018 & 0.8 \\
\hline Q2-2008 & 0.6 & Q3-2018 & 0.5 \\
\hline Q3-2008 10 & -0.5 & Q4-2018 & 0.2 \\
\hline Q4-2008 & -2.2 & Q1-2019 & 0.6 \\
\hline Q1-2009 & -1.2 & Q2-2019 & 0.8 \\
\hline Q2-2009 & -0.2 & Q3-2019 & 0.7 \\
\hline Q3-2009 & 0.4 & Q4-2019 & 0.5 \\
\hline Q4-2009 & 1.1 & Q1-202 11 & -1.3 \\
\hline Q1-2010 & 0.5 & Q2-2020 & -8.9 \\
\hline Q2-2010 & 1.0 & Q3-2020 & 7.5 \\
\hline Q3-2010 & 0.8 & Q4-2020 & 1.1 \\
\hline Q2-2021 & 1.6 & Q1-2021 & 1.5 \\
\hline Q4-2010 & 0.5 & Q2-2014 & 1.3 \\
\hline Q1-2011 & -0.2 & & \\
\hline Q2-2011 & 0.7 & & \\
\hline Q3-2011 & 0 & & \\
\hline Q4-2011 & 1.1 & & \\
\hline Q1-2012 & 0.8 & & \\
\hline Q2-2012 & 0.5 & & \\
\hline Q3-2012 & 0.2 & & \\
\hline Q4-2012 & 0.1 & & \\
\hline Q1-2013 & 0.9 & & \\
\hline Q2-2013 & 0.1 & & \\
\hline Q3-2013 & 0.8 & & \\
\hline
\end{tabular}

Notes: numbers identify start of recession, based on two negative quarters GDP growth. 
Appendix Table 5. UK Economic Conditions May 2004-March 2008. Source: Blanchflower (2008)

a) UK consumer confidence

\begin{tabular}{cc}
$\begin{array}{l}\text { Nationwide } \\
\text { consumer } \\
\text { confidence }\end{array}$ & $\begin{array}{l}\text { GFK } \\
\text { balance }\end{array}$ \\
100 & \\
106 & -2 \\
110 & -7 \\
94 & 1 \\
92 & -3 \\
84 & -7 \\
88 & -8 \\
90 & -8 \\
99 & -6 \\
95 & -2 \\
96 & -3 \\
94 & -6 \\
99 & -4 \\
98 & -7 \\
86 & -8 \\
85 & -10 \\
81 & -14 \\
78 & -13 \\
77 & -17 \\
96 & -19 \\
\hline 9 & -7
\end{tabular}

$\begin{array}{cc}\begin{array}{cc}\text { GFK future } \\ \text { economic } \\ \text { situation }\end{array} & \begin{array}{c}\text { GFK } \\ \text { major } \\ \text { purchases }\end{array} \\ -14 & 12 \\ -10 & 5 \\ -15 & 11 \\ -21 & 10 \\ -19 & 9 \\ -10 & 2 \\ -18 & 2 \\ -10 & 4 \\ -10 & 4 \\ -13 & 7 \\ -15 & -5 \\ -19 & 3 \\ -17 & -2 \\ -21 & -2 \\ -26 & -3 \\ -26 & -8 \\ -29 & -20 \\ -32 & -21 \\ -8 & -21 \\ & 8\end{array}$

b) Labor market survey - REC demand for staff

$\begin{array}{llll}\text { 28-Feb-05 } & 54.5 & \text { 30-Sep-06 } & 56.8 \\ \text { 31-Mar-05 } & 55.0 & \text { 31-Oct-06 } & 59.3 \\ \text { 30-Apr-05 } & 55.9 & \text { 30-Nov-06 } & 61.2 \\ \text { 31-May-05 } & 56.3 & \text { 31-Dec-06 } & 61.8 \\ \text { 30-Jun-05 } & 55.4 & \text { 31-Jan-07 } & 60.8 \\ \text { 31-Jul-05 } & 54.7 & \text { 28-Feb-07 } & 59.0 \\ \text { 31-Aug-05 } & 55.1 & \text { 31-Mar-07 } & 62.3 \\ \text { 30-Sep-05 } & 53.8 & \text { 30-Apr-07 } & 60.5 \\ \text { 31-Oct-05 } & 54.7 & \text { 31-May-07 } & 59.4 \\ \text { 30-Nov-05 } & 55.4 & \text { 30-Jun-07 } & 63.2 \\ \text { 31-Dec-05 } & 55.9 & \text { 31-Jul-07 } & 64.1 \\ \text { 31-Jan-06 } & 54.3 & \text { 31-Aug-07 } & 60.1 \\ \text { 28-Feb-06 } & 52.3 & \text { 30-Sep-07 } & 60.2 \\ \text { 31-Mar-06 } & 54.6 & \text { 31-Oct-07 } & 57.4 \\ \text { 30-Apr-06 } & 55.2 & \text { 30-Nov-07 } & 53.7 \\ \text { 31-May-06 } & 57.4 & \text { 31-Dec-07 } & 50.7 \\ \text { 30-Jun-06 } & 57.0 & \text { 31-Jan-08 } & 51.4 \\ \text { 31-Jul-06 } & 59.1 & \text { 29-Feb-08 } & 49.0 \\ \text { 31-Aug-06 } & 58.2 & & \end{array}$


Appendix Table 6. Annual OECD unemployment rates for 30 countries (https://data.oecd.org/unemp/unemployment-rate.htm)

\begin{tabular}{|c|c|c|c|c|c|c|c|c|c|c|c|c|c|c|c|c|}
\hline & 2005 & 2006 & 2007 & 2008 & 2009 & 2010 & 2011 & 2012 & 2013 & 2014 & 2015 & 2016 & 2017 & 2018 & 2019 & 2020 \\
\hline Australia & 5.0 & 4.8 & 4.4 & 4.2 & 5.6 & 5.2 & 5.1 & 5.2 & 5.7 & 6.1 & 6.1 & 5.7 & 5.6 & 5.3 & 5.2 & 6.5 \\
\hline Austria & 6.0 & 5.6 & 5.2 & 4.4 & 5.7 & 5.2 & 4.9 & 5.2 & 5.7 & 6.0 & 6.2 & 6.5 & 5.9 & 5.2 & 4.8 & 5.0 \\
\hline Belgium & 8.4 & 8.3 & 7.5 & 7.0 & 7.9 & 8.3 & 7.2 & 7.6 & 8.5 & 8.5 & 8.5 & 7.9 & 7.1 & 6.0 & 5.4 & .6 \\
\hline Canada & 6.8 & 6.4 & 6.1 & 6.2 & 8.4 & 8.1 & 7.6 & 7.3 & 7.1 & 6.9 & 6.9 & 7.1 & 6.4 & 5.9 & 5.7 & 6 \\
\hline Czechia & 7.9 & 7.1 & 5.3 & 4.4 & 6.7 & 7.3 & 6.7 & 7.0 & 7.0 & 6.1 & 5.1 & 4.0 & 2.9 & 2.3 & 2.0 & 6 \\
\hline Denmark & 4.8 & 3.9 & 3.8 & 3.7 & 6.4 & 7.8 & 7.8 & 7.8 & 7.4 & 6.9 & 6.3 & 6.0 & 5.8 & 5.1 & 5.1 & .7 \\
\hline Finland & 8.4 & 7.7 & 6.9 & 6.4 & 8.4 & 8.5 & 8.0 & 7.8 & 8.3 & 8.8 & 9.5 & 8.9 & 8.8 & 7.4 & 6.7 & 7.7 \\
\hline France & 8.9 & 8.9 & 8.0 & 7.4 & 9.1 & 9.3 & 9.2 & 9.8 & 10.3 & 10.3 & 10.4 & 10.1 & 9.4 & 9.0 & 8.4 & 8.0 \\
\hline Germany & 11.3 & 10.3 & 8.5 & 7.4 & 7.6 & 7.0 & 5.8 & 5.4 & 5.2 & 5.0 & 4.6 & 4.1 & 3.8 & 3.4 & 3.2 & \\
\hline Greece & 10.0 & 9.0 & 8.4 & 7.8 & 9.6 & 12.8 & 17.9 & 24.5 & 27.5 & 26.6 & 25.0 & 23.6 & 21.5 & 19.3 & 17.3 & 16.4 \\
\hline Hungary & 7.2 & 7.5 & 7.4 & 7.8 & 9.7 & 10.8 & 10.7 & 10.7 & 9.9 & 7.5 & 6.6 & 5.0 & 4.1 & 3.6 & 3.3 & \\
\hline Iceland & 2.9 & 3.2 & 2.5 & 3.3 & 8.0 & 8.3 & 7.7 & 6.6 & 5.8 & 5.4 & 4.5 & 3.3 & 3.3 & 3.1 & 3.9 & \\
\hline Ireland & 4.6 & 4.8 & 5.0 & 6.8 & 12.7 & 14.6 & 15.4 & 15.5 & 13.8 & 11.9 & 9.9 & 8.4 & 6.7 & 5.8 & 5.0 & \\
\hline Israel & 9.0 & 8.4 & 7.3 & 6.1 & 7.5 & 6.6 & 5.6 & 6.9 & 6.2 & 5.9 & 5.2 & 4.8 & 4.2 & 4.0 & 3.8 & \\
\hline Italy & 7.8 & 6.9 & 6.2 & 6.8 & 7.9 & 8.5 & 8.5 & 10.9 & 12.4 & 12.8 & 12.0 & 11.8 & 11.3 & 10.7 & 10.0 & \\
\hline Japan & 4.4 & 4.1 & 3.8 & 4.0 & 5.1 & 5.1 & 4.6 & 4.4 & 4.0 & 3.6 & 3.4 & 3.1 & 2.8 & 2.4 & 2.4 & \\
\hline Korea & 3.8 & 3.5 & 3.3 & 3.2 & 3.6 & 3.7 & 3.4 & 3.2 & 3.1 & 3.5 & 3.6 & 3.7 & 3.7 & 3.8 & 3.8 & \\
\hline Luxembourg & 4.7 & 4.6 & 4.2 & 4.9 & 5.1 & 4.6 & 4.8 & 5.1 & 5.9 & 6.1 & 6.5 & 6.3 & 5.6 & 5.5 & 5.6 & \\
\hline Mexico & 3.6 & 3.6 & 3.7 & 4.0 & 5.5 & 5.4 & 5.2 & 5.0 & 4.9 & 4.8 & 4.4 & 3.9 & 3.4 & 3.3 & 3.5 & \\
\hline Netherlands & 5.9 & 5.0 & 4.2 & 3.7 & 4.4 & 5.0 & 5.0 & 5.8 & 7.2 & 7.4 & 6.9 & 6.0 & 4.9 & 3.8 & 3.4 & \\
\hline New Zealand & 3.8 & 3.9 & 3.6 & 4.0 & 5.9 & 6.2 & 6.0 & 6.5 & 5.9 & 5.4 & 5.4 & 5.1 & 4.7 & 4.3 & 4.1 & \\
\hline Norway & 4.5 & 3.4 & 2.6 & 2.7 & 3.3 & 3.7 & 3.4 & 3.3 & 3.8 & 3.6 & 4.5 & 4.8 & 4.2 & 3.9 & 3.7 & \\
\hline Poland & 17.9 & 14.0 & 9.6 & 7.0 & 8.1 & 9.7 & 9.7 & 10.1 & 10.3 & 9.0 & 7.5 & 6.2 & 4.9 & 3.9 & 3.3 & \\
\hline Portugal & 9.2 & 9.3 & 9.6 & 9.2 & 11.2 & 12.6 & 13.5 & 16.6 & 17.2 & 14.7 & 13.0 & 11.5 & 9.2 & 7.2 & 6.7 & \\
\hline Slovakia & 16.4 & 13.5 & 11.2 & 9.6 & 12.1 & 14.5 & 13.7 & 14.0 & 14.2 & 13.2 & 11.5 & 9.7 & 8.1 & 6.5 & 5.8 & \\
\hline Spain & 9.2 & 8.5 & 8.2 & 11.3 & 17.9 & 19.9 & 21.4 & 24.8 & 26.1 & 24.5 & 22.1 & 19.7 & 17.2 & 15.3 & 14.1 & 15. \\
\hline Sweden & 7.6 & 7.0 & 6.1 & 6.2 & 8.3 & 8.6 & 7.8 & 8.0 & 8.0 & 7.9 & 7.4 & 7.0 & 6.7 & 6.3 & 6.8 & \\
\hline Turkey & 9.5 & 9.1 & 9.2 & 10.0 & 13.0 & 11.2 & 9.1 & 8.4 & 9.1 & 9.9 & 10.3 & 10.9 & 10.9 & 10.9 & 13.7 & 13 \\
\hline UK & 4.8 & 5.4 & 5.3 & 5.7 & 7.6 & 7.9 & 8.1 & 8.0 & 7.6 & 6.2 & 5.4 & 4.9 & 4.4 & 4.1 & 3.8 & \\
\hline USA & 5.1 & 4.6 & 4.6 & 5.8 & 9.3 & 9.6 & 9.0 & 8.1 & 7.4 & 6.2 & 5.3 & 4.9 & 4.4 & 3.9 & 3.7 & \\
\hline
\end{tabular}


Appendix Table 7. Annual Employment change versus 2006 level ('000s)

\begin{tabular}{|c|c|c|c|c|c|c|}
\hline Country & 2006 level & 2007-2006 & 2008-2007 & 2009-2008 & 2010-2009 & 2011-2010 \\
\hline Australia & 10,124 & 310 & 297 & 74 & 217 & 192 \\
\hline Austria & 3826 & 98 & 70 & -12 & 34 & 36 \\
\hline Belgium & 4264 & 116 & 66 & -25 & 68 & 21 \\
\hline Brazil & 87,878 & 1,353 & 2,847 & 425 & & \\
\hline Bulgaria & 3,110 & 143 & 108 & -107 & -178 & -110 \\
\hline Canada & 16,375 & 344 & 240 & -274 & 222 & 264 \\
\hline Chile & 6,340 & 299 & 197 & -54 & 350 & 356 \\
\hline Costa Rica & 1,807 & 92 & 24 & -36 & -2 & -53 \\
\hline Croatia & 3,173 & $-1,439$ & 37 & -14 & -67 & -65 \\
\hline Cyprus & 357 & 21 & 5 & 0 & 12 & 3 \\
\hline Czech Republic & 4,828 & 94 & 81 & -68 & -49 & 19 \\
\hline Denmark & 2,802 & -1 & 3 & -86 & -58 & -1 \\
\hline Estonia & 653 & 6 & -1 & -62 & -26 & 35 \\
\hline Finland & 2,467 & 44 & 43 & -76 & -12 & 28 \\
\hline France & 25,672 & 442 & 355 & -265 & 78 & 38 \\
\hline Germany & 37,250 & 833 & 559 & -63 & 255 & -3 \\
\hline Greece & 4,528 & 37 & 46 & -54 & -166 & -335 \\
\hline Hungary & 3,928 & -27 & -53 & -100 & -16 & 27 \\
\hline Iceland & 165 & 7 & 1 & -11 & -1 & 1 \\
\hline Indonesia & 95,317 & 3,440 & 3,545 & 2,377 & 3,129 & 1,924 \\
\hline Ireland & 2,039 & 177 & -22 & -182 & -90 & -36 \\
\hline Israel & 2,823 & 113 & 104 & 47 & 97 & 85 \\
\hline Italy & 22,758 & 137 & 196 & -392 & -172 & 71 \\
\hline Japan & 63,840 & 290 & -280 & $-1,040$ & -230 & $-2,820$ \\
\hline Korea & 23,188 & 373 & 213 & -87 & 345 & 494 \\
\hline Latvia & 1,031 & 26 & -2 & -146 & -58 & 11 \\
\hline Lithuania & 1,429 & 23 & -24 & -110 & -70 & 6 \\
\hline Luxembourg & 195 & 8 & -1 & 15 & 4 & 4 \\
\hline Macedonia & 570 & 20 & 19 & 21 & 8 & 7 \\
\hline Malta & 151 & 4 & 3 & 1 & 3 & 4 \\
\hline Mexico & 43,378 & 853 & 712 & 492 & 686 & 1,017 \\
\hline Netherlands & 7,950 & 233 & 189 & 3 & -85 & 1 \\
\hline New Zealand & 2131 & 37 & 7 & -29 & 10 & 32 \\
\hline Norway & 2353 & 81 & 80 & -14 & 1 & 35 \\
\hline Poland & 14,594 & 647 & 560 & 69 & -395 & 89 \\
\hline Portugal & 5,079 & 14 & 24 & -148 & -70 & -158 \\
\hline Romania & 9,291 & 62 & 16 & -126 & -531 & -185 \\
\hline Russian Federation & 69,169 & 1,602 & 233 & $-1,593$ & 523 & 923 \\
\hline Slovak Republic & 2,301 & 56 & 76 & -68 & -48 & -2 \\
\hline Slovenia & 961 & 24 & 11 & -15 & -15 & -30 \\
\hline South Africa & 13,419 & 48 & 1,274 & -406 & -396 & 256 \\
\hline Spain & 19,939 & 641 & -110 & $-1,363$ & -382 & -303 \\
\hline Sweden & 4,427 & 117 & 52 & -95 & 23 & 102 \\
\hline Switzerland & 4,051 & 71 & 107 & 39 & -60 & 90 \\
\hline Turkey & 20,421 & 318 & 455 & 83 & 1316 & 1,517 \\
\hline United Kingdom & 28,953 & 318 & 154 & -430 & 52 & 126 \\
\hline United States & 144,426 & 1619 & -684 & $-5,484$ & -813 & 803 \\
\hline EU27 & 189,003 & 2,535 & 2,285 & $-3,490$ & $-2,009$ & -734 \\
\hline Euro area & 142,851 & 2,939 & 1,482 & $-2,963$ & -739 & -610 \\
\hline
\end{tabular}

